Article

\title{
Developing a Framework for the Implementation of Landscape and Greenspace Indicators in Sustainable Urban Planning. Waterfront Landscape Management: Case Studies in Gdańsk, Poznań and Bristol
}

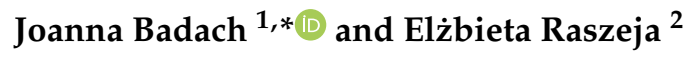 \\ 1 Department of Urban Architecture and Waterscapes, Faculty of Architecture, \\ Gdańsk University of Technology, 11/12 Narutowicza Street, 80-233 Gdańsk, Poland \\ 2 Department of Architecture and Urban Planning, Faculty of Architecture and Design, \\ University of the Arts in Poznań, Aleje Marcinkowskiego 29, 60-967 Poznań, Poland; \\ elzbieta.raszeja@uap.edu.pl \\ * Correspondence: joanna.badach@pg.edu.pl
}

Received: 3 February 2019; Accepted: 11 April 2019; Published: 16 April 2019

check for updates

\begin{abstract}
Urban landscape (UL) management and urban greenspace (UG) delivery require effective planning tools. The aim of the study is to develop a conceptual framework for the implementation of ecological, structural and visual landscape and greenspace indicators (LGI) in spatial development of urban areas. The UL and UG management provisions in Poland are identified at various levels of urban planning (local, municipal and regional). Furthermore, the applicability of the selected set of LGI in the Polish planning system is considered based on the existing planning documents. The quality of UL and UG transformation is discussed in three case studies in Bristol, Gdańsk and Poznan in the broader context of the English and Polish spatial planning systems. Bristol is used as a point of reference for the evaluation of UL and UG management in Poland and for the comparison between English and Polish landscape policies. Based on the conceptual framework and the analysis of the case studies, critical areas of UL and UG management in Poland are identified. The existing planning system often fails to ensure the continuity of landscape structures, and it does not include its preservation and enhancement to a sufficient extent. Therefore, the implementation of the proposed LGI framework could significantly improve the ecological and visual quality, as well as the structural diversity of UL and UG. Moreover, the article concludes by indicating some practical implications of the proposed LGI framework for urban planners, policy makers and other stakeholders in terms of improving the modes of governance for UL and UG management as well as of accounting for human health and well-being.
\end{abstract}

Keywords: urban spatial planning; ecological indicators; structural indicators; visual indicators; urban landscape; urban greenspace; waterfront areas

\section{Introduction}

The widely discussed issue of sustainable development for urban areas nowadays implies new challenges connected with innovative governance mechanisms at a local, national and global scale aimed at providing the inhabitants with the best quality of life $(\mathrm{QoL})$ in cities [1,2]. Novel integrated models of urban growth are required to successfully reduce the urban sprawl and the use of resources, to mitigate the effects of pollution and to minimize the impact of urbanization on natural ecosystems [3]. The protection of biodiversity in urban areas and the development of urban systems compatible with urban greenspace are also widely discussed and alternative urban patterns are sought in order to 
protect ecosystems and the services they provide [4,5]. This is because it is widely acknowledged that the quality of urban landscape (UL) and urban greenspace (UG), and the way they are shaped and transformed within the process of urban planning, is inseparably linked to the improvement of the quality of life in urban areas as well as human health and well-being, which has been explored and reviewed in many recent studies (see, e.g., [6-10]). Urbanization and human economic activities have a significant effect on the landscape, causing fragmentation of its patterns, and on the environment, leading to a widespread concern about its protection [11,12]. Therefore, integrated urban planning or integrated environmental assessment in support of planning and management of urban areas are becoming increasingly advocated among scientists, urban planners and decision makers [13-15].

As the city is viewed as a complex social-ecological ecosystem, various novel land-use planning, management and research tools should be constructed in order to explore it from this perspective $[1,16]$. On the other hand, urban space is increasingly perceived from the perspective of urban ecology and landscape urbanism, which gives new insights into the understanding of urban ecosystem transformation and implies new methodologies for urban research [17]. Therefore, the ecological, visual and cultural aspects cannot be separated in the UL and UG research, neither in sustainable planning and spatial management. However, integrating the terminologies and methodologies of various landscape research still remains an unresolved issue [18]. Therefore, from the protection, planning and management point of view, standarized and applicable methods of assessing the structure and functioning of landscape are needed. On the other hand, for the purposes of urban and landscape planning, methods for identification, interpretation and evaluation of the quality of landscape are important for its creative transformation and for planners and decision makers. Moreover, attempts should be made to develop an interdisciplinary collaboration and to combine scientific research agenda with the local knowledge of various stakeholders [19].

The aim of this article is to develop a framework for the implementation of ecological, structural and visual landscape and greenspace indicators (LGI) in the process of sustainable urban planning. To achieve this goal, four intermediate steps are set:

1. to select and compare ecological, visual and structural LGI relevant for urban areas based on a literature study;

2. to identify the existing provisions in the Polish spatial planning system, intended for UL and UG management and preservation, based on planning documents for waterfront areas in Gdańsk and Poznań;

3. to tentativelyindicate the applicability of the selected LGI in the planning and spatial management of urban and metropolitan areas in Poland at different spatial planning levels;

4. to compare the policies for the development of waterfront areas within the process of urban planning based on three selected case studies in Bristol, Gdańsk and Poznań.

\section{Conceptual Framework-LGI in Relation to Urban Areas}

An indicator-based approach is advocated in sustainable urban planning as it provides a solid empirical base to advice the process of decision making [20]. A set of indicators for urban morphology, in which the information regarding the three-dimensional urban structure is included, is developed and researched for the purpose of monitoring and management of urban growth [21-23]. For example, a set of urban metrics was proposed as a new approach towards the analysis of the built-up structures and their morphological properties as well as the prediction of urban dynamics [22]. They are also coupled with a variety of other indicators, e.g., the relationship between urban planning indicators (such as floor area ratio, building density etc.) and climate indicators (e.g., daily maximum and minimum surface temperatures) was investigated [24]. However, these indicators may not be sufficient to cover the visual and ecological complexity of UL and UG. Therefore, the application of LGI for the monitoring and management of urban and metropolitan areas and their ecological structure should still be researched and developed. 
To evaluate ecological and visual structure and diversity, in the past years many different LGI have been developed and applied in urban areas. Currently, the research is mainly focused on the search for a common platform for combining two types of LGI: the ecological and the visual [25,26]. However, as was stressed by Antrop, the contribution from three main fields can be recognized in landscape research: the natural sciences, the human sciences and the applied sciences such as landscape architecture and urban planning [27]. Based on this division, in this work the following categorization of LGI is proposed: ecological (corresponding to natural sciences), structural (corresponding to applied sciences) and visual (corresponding to human sciences). A detailed description of the three groups of indicators is given in the following paragraph. It can be generally stated that while ecological indicators refer to ecological function, which is based on the theory of landscape ecology and defined by quantitative metrics, visual indicators pertain to aesthetic assessment, both objective and subjective (based on landscape perception and preferences) $[25,28,29]$. Another group of indicators is also proposed: structural indicators. Although in ecological indicators some attributes of landscape structure and spatial arrangement of landscape elements are included [25], it is aimed to distinguish a separate group which apply in particular to the form, distribution and spatial diversity of UG which has a relevant planning function. In such an approach, ecological indicators relate to ecological performance, ecosystem functions and biodiversity.

\subsection{Ecological Indicators}

Spatial patterns and habitat fragmentation have a significant impact on the ecological processes and thus landscape patterns are investigated to evaluate biodiversity and ecological quality of landscape [30]. Therefore, landscape metrics (LM) based on the model of patches, corridors and matrices, are developed for the assessment of landscape complexity and serve as indicators of changes in landscape structure and land use or habitat and landscape regulating functions [31]. They are also a useful instrument in the identification of urban growth patterns in both urban and suburban areas and in the exploration of future scenarios of growth options as well as their ecological consequences in metropolitan areas [32-34]. Their other applications include the association between the features of composition and configuration of land cover, measured by a set of LM, and the land surface temperature, which was examined in order to determine the impact of urbanization on urban heat islands [35]. The relationship between urban spatial structure, quantified by urban LM, and air quality was also investigated [36], together with the possibility of using landscape pattern indicators for predicting particulate matter air pollution [37]. LM can be efficiently used as indicators of the combined exposure to urban noise and particulate matter pollution in cases where no directly measured data is available [38].

Landscape and land-use change have a significant impact on ecological processes and biodiversity, concerning both the fragmentation of green areas and the modification of habitat type $[39,40]$. Therefore, various biodiversity indicators based on urban form and spatial management are developed for practical application, to be used by conservationists and spatial planners, and are linked to spatial structure at various scales [41]. However, according to some researchers, obtaining some of the ecological indicators requires multitude of research procedures and varied measurements and measurement systems, thus reducing their comparability [42]. On the other hand, attempts have been made to develop a simple set of ecological performance indicators for urban areas, which require minimum input information, in order to use it as a planning tool aimed at comparing existing urban areas and forecasting ecological impact of urban transformation [39].

\subsection{Structural Indicators}

In this article, structural indicators are understood as indicators aimed at monitoring and developing multidimensional diversity of UL and UG. A group of such indicators, also referred to as eco-spatial indices, is commonly applied in the practice of planning and spatial management of urban areas. They have been used in various countries as urban design tools to supplement planning 
provisions intended to facilitate the creation of sustainable environment [43]. These include the Biotope Area Factor (BAF), Green Space Factor (GSF), and Seattle Green Factor (SGF), in which the requirements regarding the biologically vital elements and landscaped areas in relation to the development area are determined. Some of them can be applied in various types of urban areas (BAF, SGF) $[44,45]$, and others pertain only to residential developments (GSF) [46]. The above-mentioned structural indicators are applied at the scale of a single development. However, at different scales other indicators are required, e.g., in the scale of several urban quarters Urban Neighborhood Green Index (UNGI) may be applicable [47]. For a wider regional and metropolitan scale the land cover variance indicator (LCVI) was developed to measure spatial transformations resulting from changes in various land cover [48].

As UL and UG are also associated with the provision of services which have the characteristics of public goods [49], the aspect of their accessibility and their role in improving health and well-being of urban residents should be also considered in spatial planning and management. Therefore, another type of structural indicator is used in order to evaluate the accessibility and to develop standards for the provision of UG such as the Accessible Natural Green Space Standards (ANGSt). The standard defines minimum distances to be covered by the urban residents to get to the natural environment, taking into account many other issues such as the improvement of naturalness and connectivity between UG [50,51]. Modeling the patterns of accessibility to UG has been significantly facilitated by the development of the Geographic Information System (GIS) technology, by means of which the amount of green areas and the population within a particular area can be evaluated [52,53]. For example, a set of accessibility indicators was developed based on GIS in which the ease of reaching UG destinations is considered [53]. Statistical methods are also commonly applied for the purpose of accessibility evaluation [54]. However, as recent studies have suggested, the geographic access or proximity have a lesser impact on encouraging the residents' use of UG than the perceived access. Thus, the perception and preference aspects should be investigated in spatial planning along with ensuring the physical accessibility criteria [55]. Other factors playing a mediating role between UG attributes and its usage, namely attitude, perceived usefulness and perceived behavioral control, have also been investigated [56].

\subsection{Visual Indicators}

Many researchers acknowledge that UL provides urban open space with cultural heritage [57]. The attractiveness of landscape scenery determines its evaluation and, in consequence, spatial decisions [58]. Therefore, the perception of visual features and character of the landscape is also underlined in the European Landscape Convention [59]. In visual landscape assessment, interpretative and descriptive indicators often prevail over numeric indices by means of which the quality and value of landscape cannot be fully expressed [29]. These indicators are derived from various fields of landscape architecture, art, behavioral psychology and cultural geography. Visual landscape assessment criteria can be divided into two approaches: the objective, which pertains to the aesthetic quality as an integral part of landscape and the environment, and the subjective, which is based on the psychological approach of the beholder $[29,60,61]$.

The observer-based visual landscape assessment methods can be divided into two main types: preference and expert assessment [62,63]. The former is conducted in order to determine social preferences based on the analysis of the respondents' perception of the landscape features [60]—as exemplified by indicators based on visual landscape preferences listed in Table 1 . The latter is carried out for the purposes of protection programs, development plans, projects and location decisions. The expert assessment methods include, e.g., Visual Impact Assessment (VIA), which was developed to evaluate the impact of various human interventions on the surrounding environment and to reduce the visual contrast with their settings [64]. It is still widely used, also coupled with GIS-based methods, e.g., for the evaluation of visual impact of large-scale renewable-energy facilities $[65,66]$ or in the investigation of visual effects of tall buildings [67]. Nowadays, digital analysis 
is also becoming an increasingly useful tool in visual landscape evaluation [68-70]. The digital tools are used for the purpose of landscape analysis in order to parameterize its character, e.g., by establishing a set of numerical indicators of the content of panoramic views, which makes it possible to objectify the expert landscape evaluation [69]. The classification of ecological, structural and visual LGI, as described in this subsection, as well as their objectives and methodological assumptions, are summarized in Table 1.

\subsection{Integrating $L G I$}

The necessity of integrating empirically supported human perception needs and preferences for the utilized variables when monitoring landscape and greenspace structures is underlined [82]. However, landscape aesthetic indicators are often criticized due to their subjectivity: lack of standardization in methodology, the non-transparent application of values and lack of replicability $[76,83]$. Moreover, some studies suggest that social perception is not always compatible with ecological functions [84]. Yet, there is a strong connection between the visual perception and the ecological structure of landscape which justifies the need to create a set of indicators which pertain to these two aspects and to investigate the potential integration of visual and ecological LGI [25,26]. This creates a new platform for landscape research in which landscape ecology and landscape architecture are integrated. As these two fields of research vary in terms of methodology and terminology of the landscape characterization, their comparability, legibility and unambiguity often remain an unresolved issue. Much of the interdisciplinary research was focused on searching for a common set of criteria and indicators. Various theoretical and methodological filters were used in this process such as theoretical base, comparability, the possibility of mapping, suitability for the local context and the availability of sources $[25,81]$. Moreover, from the point of view of urban planning and spatial management, the structural LGI should be also incorporated in order to develop an interdisciplinary set of indicators.

The interrelationship between ecological, structural and visual LGI for urban areas is tentatively determined and depicted in Figure 1. Selected LGI attributes, developed and applied in various fields of landscape research, are presented. In each of these fields, various research areas, tools or scientific language are applied but they are linked though a common subject of research-landscape. Therefore, the interdependence between various indicators attributes is evident, despite the fact that they may be described in accordance with the terminology appropriate for a given domain. Sometimes they pertain to the same landscape features, but their characterization may vary in terms of approach and research perspective. For example, biodiversity (attributed to ecological indicators) may be associated with complexity of landscape composition (attributed to visual indicators). Similarly, ecological composition and configuration may be associated with coherence and legibility, while continuity-with landscape visual scale (openness) $[25,81,85]$. Structural indicators in turn describe the above-mentioned landscape features in relation to space by means of its parameters (proportions, scale, form, distribution, variability and the share of particular elements). The selection of indicators derived from various research backgrounds is justified by the multidimensional character of landscape. This implies the need to conduct interdisciplinary analyses. However, selected indicators should result from the context and the aim of the research as well as the character of space. Therefore, it is not aimed to create a final, versatile set of LGI but rather to promote integrated approach towards landscape research. This is necessary for the analysis of increasingly complex spatial phenomena, resolving landscape transformation issues, and making decisions regarding the character and scope of activities in terms of protection, development, recreation and re-cultivation. It is also important in the process of creating sustainable urban structures. Nevertheless, the varied terminology or different strategies for collecting and processing data may remain a challenge. On the other hand, objectivity, clarity, reliability and accuracy of data contribute to overcoming the barriers [18]. 
Table 1. Selected LGI relevant in the process of urban planning and spatial management of urban areas (own elaboration).

\begin{tabular}{|c|c|c|c|c|}
\hline & Name & Objective & Methodological Assumptions & Ref. \\
\hline \multirow{3}{*}{ 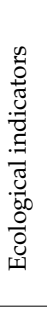 } & $\begin{array}{l}\text { Landscape metrics (LM) } \\
\text { (or landscape indices) }\end{array}$ & $\begin{array}{l}\text { - developed to quantify landscape patterns } \\
\text { - indicators for regulation, habitat, production, } \\
\text { information and carrier functions }\end{array}$ & $\begin{array}{l}\text { - in urban areas, they can be used, e.g., for the evaluation of landscape fragmentation } \\
\text { - various metrics are developed such as percentage of landscape, largest patch index, patch } \\
\text { density, total edge, edge density, landscape shape index etc. }\end{array}$ & {$[30,31,71-73]$} \\
\hline & $\begin{array}{l}\text { Indicators for the ecological } \\
\text { performance }\end{array}$ & $\begin{array}{l}\text { - indicators to measure the impact of land use } \\
\text { and surface cover on ecological performance }\end{array}$ & $\begin{array}{l}\text { - the set contains climate, hydrology, carbon storage and sequestration, } \\
\text { and biodiversity indicators } \\
\text { - input information regarding the proportion of various surface cover is required }\end{array}$ & [39] \\
\hline & $\begin{array}{l}\text { Biodiversity indicators for urban } \\
\text { and suburban parks }\end{array}$ & $\begin{array}{l}\text { - intended for monitoring biodiversity, both in } \\
\text { terms of habitat and species diversity, in UG } \\
\text { (urban and suburban parks) }\end{array}$ & $\begin{array}{l}\text { - diversity and saturation index are calculated for the selected habitat units divided into } \\
\text { planar, linear and punctual elements } \\
\text { - four species groups serve as an indicator for biodiversity }\end{array}$ & [41] \\
\hline \multirow{5}{*}{ 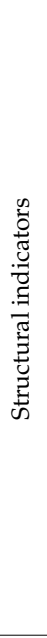 } & $\begin{array}{l}\text { Eco-spatial indices: Biotope area } \\
\text { factor (BAF), Seattle Green Factor } \\
\text { (SGF), Green Space Factor (GSF) }\end{array}$ & $\begin{array}{l}\text { - sets of standards for new inner-city or } \\
\text { residential developments intended for } \\
\text { the protection and creation of high quality UG } \\
\text { in terms of biodiversity, appearance, } \\
\text { recreational use, visibility and availability }\end{array}$ & $\begin{array}{l}\text { - different types of biologically active surfaces are scored with different weighting according } \\
\text { to their ecological value (from } 0 \text { to } 1 \text { ) } \\
\text { - calculated as the total of ecologically effective areas divided by the total land area } \\
\text { - a target degree of coverage is set depending on the type of urban zone, urban forms of use } \\
\text { etc. and additional score can be given for various landscape features }\end{array}$ & [44-46] \\
\hline & $\begin{array}{l}\text { Urban Neighborhood Green Index } \\
\text { (UNGI) }\end{array}$ & $\begin{array}{l}\text { - developed as a simple technique to quantify } \\
\text { UG quality by means of Remote Sensing } \\
\text { and GIS technologies } \\
\text { - a decision support tool }\end{array}$ & $\begin{array}{l}\text { - various parameters are measured (e.g., percentage and classification of green areas and their } \\
\text { proximity, density and heights of the built-up structures) } \\
\text { - it provides data on the amount, distribution and characteristics of UG, vegetation } \\
\text { and built-up structures }\end{array}$ & [47] \\
\hline & Land cover variance indicator (LCVI) & $\begin{array}{l}\text { - aimed at defining the scale of current } \\
\text { and future changes in land cover }\end{array}$ & $\begin{array}{l}\text { - calculated according to a formula in which the input data include the past, the current or } \\
\text { forecasted areas of different land covers (e.g., forested areas, farmlands, wetlands, built-up } \\
\text { areas, roads and open waters) }\end{array}$ & [48] \\
\hline & $\begin{array}{l}\text { Accessible Natural Greenspace } \\
\text { Standard (ANGSt) }\end{array}$ & $\begin{array}{l}\text { - designed to define the accessibility distance } \\
\text { thresholds from residential developments to } \\
\text { natural sites }\end{array}$ & $\begin{array}{l}\text { - at least 2-ha natural greenspace should be provided no more than } 300 \mathrm{~m} \text { from each home, } \\
20 \text {-ha- } 2 \mathrm{~km}, 100 \text {-ha }-5 \mathrm{~km} \text { and } 500 \text {-ha }-10 \mathrm{~km} \\
\text { - a minimum of } 1 \text { ha of Local Natural Reserves is required per one thousand residents }\end{array}$ & [51] \\
\hline & Accessibility indicators & $\begin{array}{l}\text { - aimed at modeling the accessibility } \\
\text { and the ease of reaching UG } \\
\text { - applied at various functional levels (from } \\
\text { district to city level) }\end{array}$ & $\begin{array}{l}\text { - three types of accessibility measures are usually considered (Euclidean or Manhattan } \\
\text { distance, which can be easily calculated by means of GIS, as well as network distance } \\
\text { which requires additional dataset, e.g., regarding the roads network) }\end{array}$ & {$[52,53,74,75]$} \\
\hline \multirow{4}{*}{ 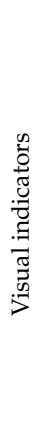 } & $\begin{array}{l}\text { Visual preferences landscape } \\
\text { indicators }\end{array}$ & $\begin{array}{l}\text { - created to investigate landscape visual quality } \\
\text { and aesthetics assessment of its recipients } \\
\text { (potential users) }\end{array}$ & $\begin{array}{l}\text { - based on numerical rating of the observers' preferences } \\
\text { - e.g., indicators of perceived naturalness, scenic beauty estimation (SBE), visual aesthetic } \\
\text { quality (VAQ) assessment, indicators of visual scale, GIS-based visual preferences indicators }\end{array}$ & {$[25,29,61,76-78]$} \\
\hline & $\begin{array}{l}\text { GIS-based landscape appreciation } \\
\text { model (GLAM) indicators }\end{array}$ & $\begin{array}{l}\text { - based on a paradigm according to } \\
\text { which landscape attractiveness is linked to its } \\
\text { physical characteristics }\end{array}$ & $\begin{array}{l}\text { - the interrelationships between six indicators (naturalness, relief, historical distinctiveness, } \\
\text { skyline disturbance, urbanity and noise level) are calculated on a mapped grid } \\
\text { - each cell is assigned with a score from } 0 \text { to } 4 \text { based on predetermined criteria }\end{array}$ & [79] \\
\hline & Landscape visual character indicators & $\begin{array}{l}\text { - a preliminary scheme for the analysis } \\
\text { and characterization of landscape } \\
\text { visual character } \\
\text { - based on preference and experience theories }\end{array}$ & $\begin{array}{l}\text { - based on nine key concepts (stewardship, coherence, disturbance, historicity, visual scale, } \\
\text { imageability, complexity, naturalness and ephemera) which are assigned with various } \\
\text { indicators, existing in literature and empirically tested }\end{array}$ & {$[80,81]$} \\
\hline & $\begin{array}{l}\text { Indicators based on the digital } \\
\text { panoramic view analysis }\end{array}$ & $\begin{array}{l}\text { - objective evaluation and parameterization of } \\
\text { landscape attractiveness based on digital } \\
\text { panoramic views analysis }\end{array}$ & $\begin{array}{l}\text { - establishing a set of numerical indicators of the content of panoramic views (e.g., the surfaces } \\
\text { of the particular elements, the degree of compactness or fragmentation of landscape forms) }\end{array}$ & [69] \\
\hline
\end{tabular}




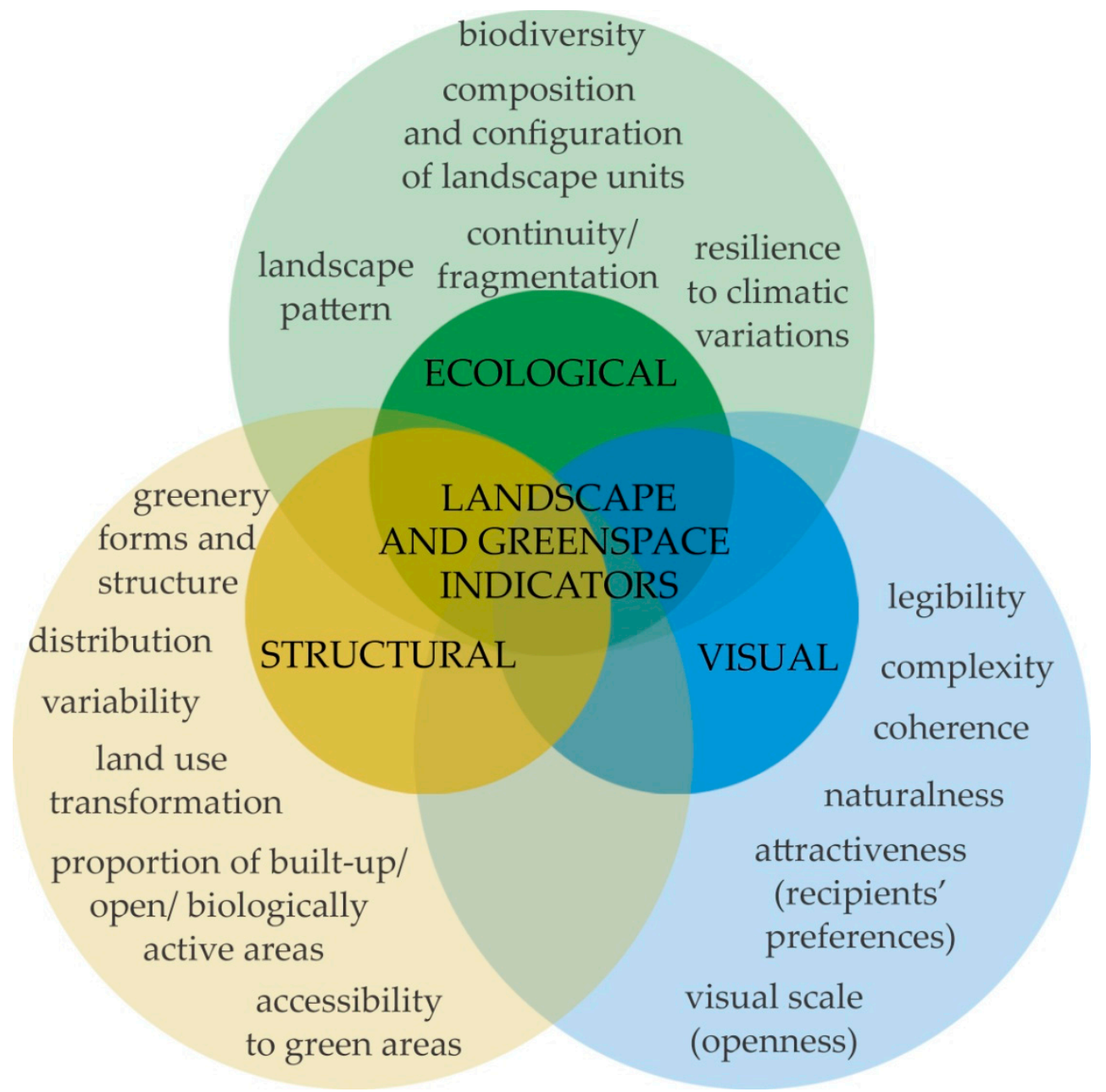

Figure 1. Interrelationship between ecological, structural and visual LGI relevant for urban planning (own elaboration).

\section{Materials and Methods}

\subsection{Research Methods}

The empirical study is preceded by developing a conceptual framework for integrating ecological, structural and visual LGI. It is based on an extensive literature study and on secondary data obtained from other research which were focused on LGI applicable to urban areas. Subsequently, in the first phase of the research, information on UL and UG protection and management is extracted from local, municipal and regional planning documents for the selected study areas in Gdańsk and Poznań (available at Gdańsk Municipal Office, Gdańsk Development Office, Pomeranian Land Management Office, Poznań Municipal Urban Planning Office and the Centre for Metropolitan Research UAM Poznań, as referenced in Section 4). To explore the theoretical framework for the implementation of the selected LGI in Polish spatial planning system, the UL and UG provisions within the planning documents are identified. Subsequently, a proposal for the application of the selected LGI in the Polish planning instruments at different levels is developed. In the last phase of the research, preliminary conclusions on the impact of spatial planning systems on the quality of UL and UG are drawn based on three case studies of waterfront areas in Bristol (England) and in Gdańsk and Poznań (Poland).The scheme of the proposed methodological approach for the research is presented in Figure 2. 


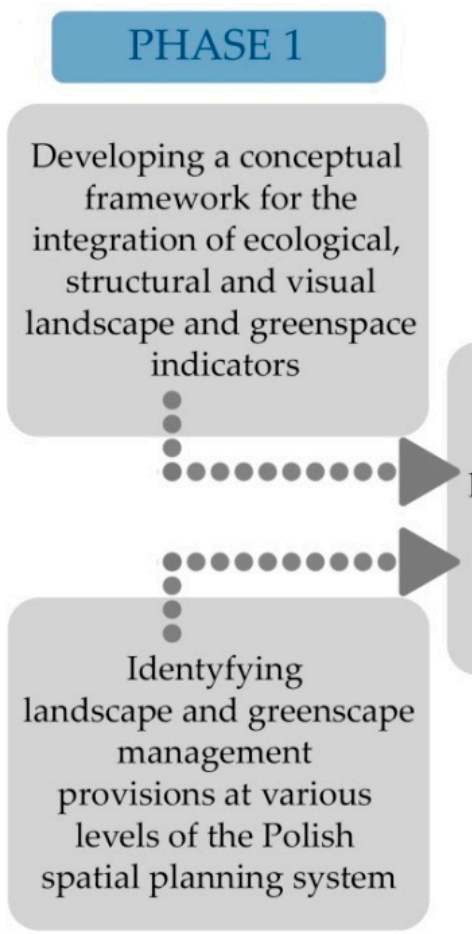

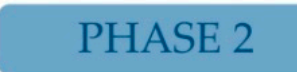

PHASE 2

Preliminary assigning the selected

landscape and greenspace indicators to the existing

Polish spatial planning instruments

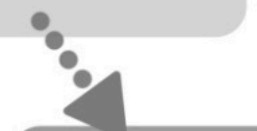

Developing a framework for the implementation of ecological, structural and visual landscape and greenspace indicators

in the process of sustainable urban planning

\section{PHASE 3}

Comparing landscape and greenspace management policies in Polish and British planning system based on three case studies: Bristol, Gdańsk and Poznań

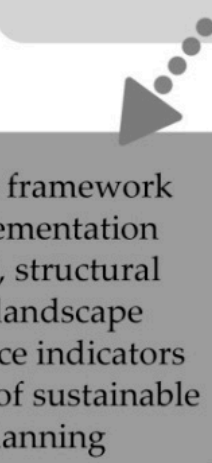

\section{RESEARCH OBJECTIVE}

Figure 2. Scheme illustrating the methodological approach of the study (own elaboration).

\subsection{Study Areas}

Waterfront areas of three cities: Bristol, England ( $\left.51.45^{\circ} \mathrm{N}, 2.58^{\circ} \mathrm{W}\right)$, Gdańsk, Poland $\left(54.35^{\circ} \mathrm{N}\right.$, $\left.18.64^{\circ} \mathrm{E}\right)$, and Poznań, Poland $\left(52.40^{\circ} \mathrm{N}, 16.92^{\circ} \mathrm{E}\right)$, are subjected to analysis. The built environment in these cities is integrated with rivers as dominant natural elements to a varying extent. The relationship between visual attractiveness and ecological value in the presented case studies is discussed. Bristol is chosen as a point of reference (in juxtaposition to Gdańsk and Poznań) due to its spatial policy, which is highly integrated with landscape policy, which can be exemplified by the river Avon waterfront redevelopment. The regeneration of the waterfront was successful due to the inclusion of several urban, landscape, cultural and social aspects during its development [16]. Due to such policies, Bristol became the 2015 European Green Capital [86]. The specified study areas are located close to the city centers, characterized by high historical value and currently undergoing the process of revitalization. The location of the cities on the country maps, the location of the study areas within their urban structure and the specified study areas are depicted in Figure 3.

The river Avon has been of strategic importance for the rapid urban expansion and industrialization of the city of Bristol. However, over centuries, the development of the port led to the degradation of the environment and the riverside landscape [87]. Since the 1980s, the harbor side area has been under a regeneration program, which over the past 15 years has been based on an overall plan and on a coherent landscape concept, designed by Grant Associates studio. Both ecological aspects (the continuity of natural systems, biodiversity, local climate, water treatment) and visual aspects (visual attractiveness and accessibility, view openings and compositional relations) have been taken into consideration in this plan [88]. 
The urban structure of Gdańsk was determined by its location by the Motława Channel. Since medieval times, the development of the city has been connected with the international port and trading activity. The waterfront area was used extensively for warehouses and port facilities. Demolished in the WWII, it was rebuilt, and it serves nowadays as a vital touristic area.

The location and development of Poznan is connected with the Warta river valley, which can be described as an ecological and landscape axis of the city. Throughout the centuries, the spatial transformation of the city led to "turning away" from the river, especially in the post-war period. Yet, the river still constitutes a crucial element of the urban ecosystem, and the municipal system of the green wedges and rings greenery is based on its tributaries [89].
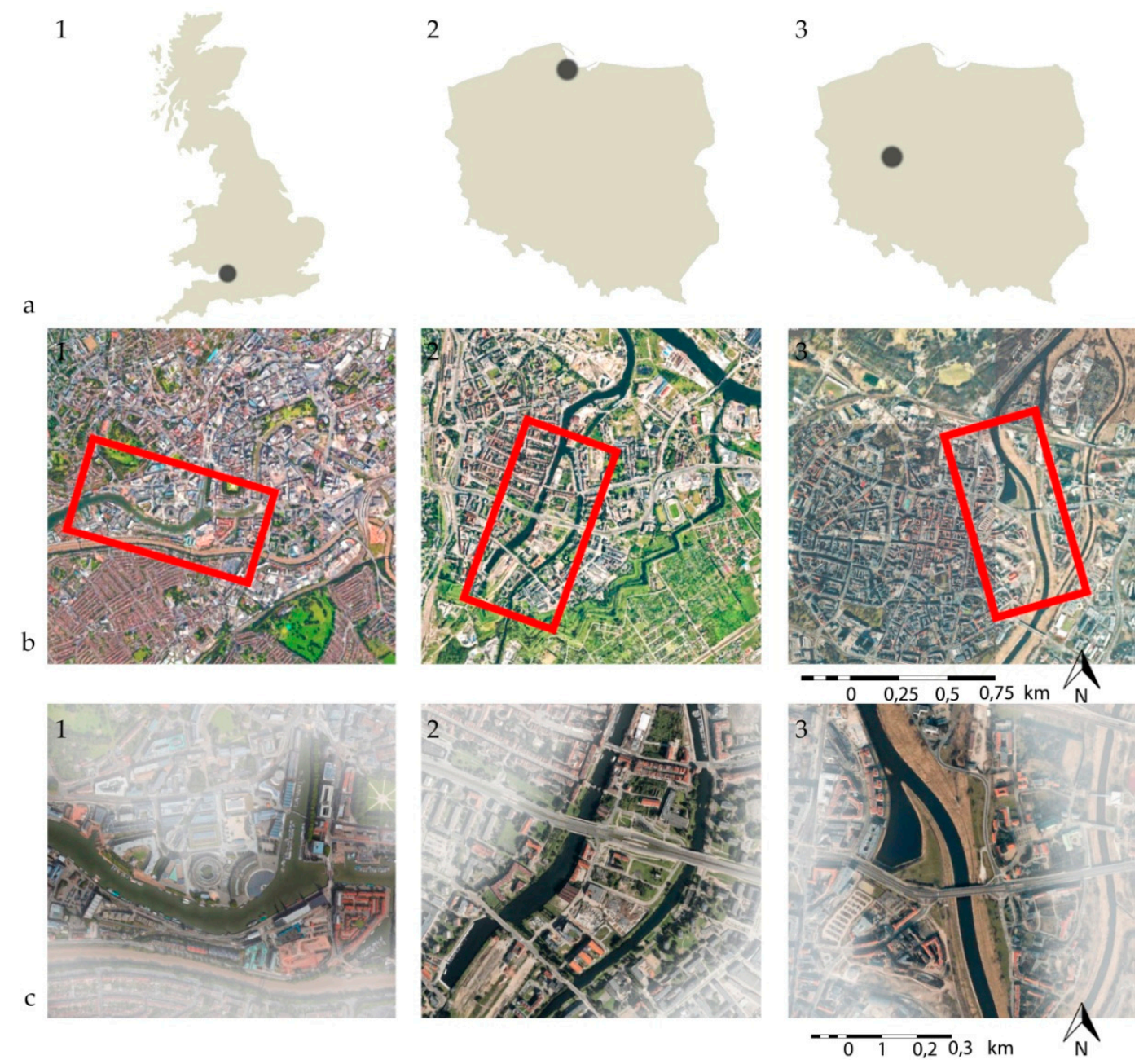

Figure 3. (a) the location of the cities subjected to empirical study: 1-Bristol (England), 2-Gdańsk (Poland), 3-Poznań (Poland); (b) the location of the study areas within the urban structure of the cities; (c) the specified study areas.

\section{Results and Discussion}

\subsection{Applicability of LGI in the Polish Spatial Planning System with Regard to English Experiences}

The application of particular LGI is dependent on the structure of the planning system in various countries, legal bases and employed instruments (planning documents). The structure of the spatial planning system in Poland is hierarchical and based on three levels of government structures and administration: national, provincial and municipal. The Act on Spatial Planning (ASP) defines the set of instruments and procedures for the realization of spatial policy by the government administration and local authorities [90]. The arrangements of the Proposal for Spatial Development of 
the Country are mandatory for the Provincial Spatial Development Plans (PSDP). These plans, in turn, take precedence over the Studies on Conditions and Spatial Development Directions for Municipalities (SCSDDM). The basic spatial planning tool takes the form of the Local Spatial Development Plan (LSDP) which constitutes the grounds for land management, issuing decisions regarding land use for investment purposes as well as decisions regarding the conversion of existing land use. LSDP do not cover the area of the entire municipality. On the contrary, it is divided into many separate LSDP which are varied in terms of their provisions. For example, in many Polish cities there are several dozen valid plans. The ASP has also introduced the term of metropolitan area, which is defined as the area of a major city and the functionally connected surrounding zones. For these areas, another type of plan was introduced — the Spatial Development Plan for Metropolitan Area (SDPMA)—which constitutes a part of the PSDP.

Indicators should provide objective and comprehensible information on the current state, allow for the identification of development trends and reveal problem areas in which planning activities should be undertaken [91]. Therefore, it is important to discuss the contribution of LGI in urban planning in relation to existing planning instruments and their provisions. According to reference publications, the indicators, in order to be useful in the process of decision-making, should comply with the following criteria: relevance to policy, scientific credibility, usability for policy makers and feasibility for implementation [63]. Moreover, in the assessment of UL and UG for the purposes of spatial planning at different scales it is necessary to relate it to the level of landscape complexity. As it was discussed by Jessel in the case of visual landscape, its levels of complexity and the corresponding criteria which can serve as indicators for them may be divided into three categories: (1) element level, which is described by its particular elements and their individual composition in the place scale; (2) shape level, with a higher degree of complexity characterized by the area specific composition and configuration of spatial patterns; (3) space level, which is described by general reception of the landscape character in a broader, e.g., regional, scale [82].

This division (place, local and regional scale) corresponds with the scales of planning instruments. In the article, this referred to municipal planning documents in Poland, which vary in scale, range and the level of complexity of spatial issues. From this perspective, LSDP correspond to the Jessel's element level (1), SCSDDM with the shape level (2) and SDPMA with the space level (3). The instrumental provisions regarding landscape management and greenspace delivery in urban areas within the existing planning system levels in Poland are first identified. At the element scale, it is important to diagnose and recognize characteristic elements, such as greenery and architecture, which should constitute a basis for the plans for land use and land cover, the parameters of the built structures and the forms of greenery systems. However, based on the analyzed planning documents for the study areas, very often specific provisions in LSDP regarding the structure of greenspaces are omitted, such as the diversification of elements, the parameters or visual features of high vegetation, analysis of accessibility or the visual barriers, openings, etc.). Moreover, in terms of biodiversity, provisions regarding protection of species composition of the remaining natural habitats and adoption of these species in the development of new green infrastructure are very rare.

The provisions in the SCSDDM are aimed at establishing the local conditioning and defining future directions of spatial policies. However, as it is a basis for the more specific LSDP, it should contain more practical guidelines and tools to implement the established objectives at the lower spatial planning level and should be preceded by a characterization of the landscape and an evaluation of the spatial forms and patterns typical for particular landscape units. Moreover, some suggested directions for spatial development are inconsistent with the proposed vision of a compact city and lead to a further degradation of semi-urban landscape (e.g., the continuous development of peripheral residential districts). At the metropolitan scale, it is necessary to synthetically delimit, identify and evaluate landscape types as a basis for the determination of directions and intensity of development. Therefore, SDPMA contains provisions of a strategic character, especially in terms of describing and inventorying the existing state through environmental, urban, social, statistical research, 
but also a set of general objectives and development directions of the spatial management policy. A set of indicators is assigned to enhance the existing provisions for the study areas in Gdańsk and Poznań which is applicable in the three aforementioned planning scales. The results of the study are presented in Table 2.

It can be generally concluded that UL and UG management in Poland is not sufficiently integrated with spatial planning at various levels, as exemplified by the provisions and instruments discussed in Table 2. Despite the fact that the cities in Poland, among other Eastern EU countries, generally exhibit relatively high ratio of residents' accessibility to greenspaces, as shown by a recent study [97], ensuring the ecological, structural and visual quality of these greenspaces remains a different issue. To effectively improve the quality of green infrastructure, its management should be more closely integrated with strategic and planning documents at both local and regional scale in the form of mandatory provisions [98]. Moreover, in a multi-scale approach, two implementation scenarios can be distinguished: an administrative one, which is led by municipal authorities, and a bottom-up one, in which local initiatives and various funding streams play a vital role, as exemplified by the analysis of green infrastructure planning in Warsaw [99]. However, at the local level of spatial planning, the RBVA still remains the most commonly applied eco-spatial index for the UG development. It is easy to implement as an urban planning measure due to its simplicity, but it is often applied incidentally as there is a lack of empirical evidence regarding the proper share of biologically active areas for different land uses [43]. It is also insufficient to comprehensively address the environmental performance and visual complexity of UG. Therefore, the supplementation of existing provisions by various LGI, discussed in this work, could significantly contribute to spatial planning in terms of improving biological, structural and, especially, visual landscape diversity in urban areas.

In the recent years, new planning standards have been developed in Poland, although not yet fully applied, based on the experiences from other European countries, such as the Warsaw Housing Standard [100], which is aimed at improving the QoL in residential areas also in term of accessibility and diversity of UG. Landscape management and protection tools are also developed by means of the Act on amending certain other acts in connection with the reinforcement of the landscape protection instruments (the so-called "Landscape Act"). It imposes the necessity of establishing municipal resolutions on landscape protection. By its means the Landscape Audit tool is introduced which is aimed at the identification of landscape types, selection of homogeneous landscape units and indication of the priority areas [101]. Although the "Landscape Act" was established with the objective of creating new quality of landscape policy in Poland, its effectiveness cannot yet be evaluated. The municipal landscape resolutions are currently drafted while the regulations concerning the preparing of Landscape Audits are still not approved. The draft regulations were already subjected to professional consultation; however, they raise serious doubts on the part of both planners and academics.

In Great Britain, landscape character and management has been integrated into the spatial planning policy over the past years by means of the Landscape Character Assessment (LCA) program which was launched to identify, describe and map the variation in landscape character and to evaluate the value of landscape [102]. The issue of protection and provision of green spaces within urban areas is also a part of planning strategies at local, regional and national level. The former can be exemplified by the Planning Policy Guidance in which three standards for the provision of accessible green areas are set regarding their features, distribution within the city and minimum area of different types of green space (the quality, distance and quantity standards) [103]. Moreover, ANGSt is recommended by the government advisory agency Natural England to be implemented in urban planning [51]. However, the proposed standard is still not yet fully met in some urban areas. Moreover, the accessibility to UG vary significantly for different social groups [104]. More UL and UG planning strategies and indicators are applied within various planning tools. 
Table 2. The provisions regarding UL management and the delivery of UG in the existing Polish planning instruments and the proposed LGI which can be applied in these documents (own elaboration based on reference publications).

\begin{tabular}{|c|c|}
\hline $\begin{array}{l}\text { Existing Planning Instruments and Their Provisions } \\
\text { Regarding UL Management and the Delivery of UG }\end{array}$ & $\begin{array}{l}\text { Recommendations for Improving the Effectiveness of the Existing Instruments and Provisions by Means of LGI } \\
\text { in Terms of Sustainable Landscape Transformation }\end{array}$ \\
\hline \multicolumn{2}{|l|}{ 1. Element level-LSDP for Gdańsk and Poznań $[92,93]$} \\
\hline $\begin{array}{l}\text { - identifying and protecting valuable elements of } \\
\text { vegetation, UG and open watercourses }\end{array}$ & \multirow{3}{*}{$\begin{array}{l}\text { Ecological indicators: } \\
\text { - indicators for the ecological performance are recommended at the element level, as they are relatively easy to use } \\
\text { as an urban planning tool [39] } \\
\text { - biodiversity indicators for urban and suburban parks can be also used }\end{array}$} \\
\hline - supplementing existing high vegetation & \\
\hline $\begin{array}{l}\text { - improving the efficiency existing water relations } \\
\text { and drainage systems }\end{array}$ & \\
\hline $\begin{array}{l}\text { - formulating minimum Ratio of Biologically Vital Areas } \\
\text { (RBVA) or minimum recreational UG per the total } \\
\text { development area or the building usable floor area }\end{array}$ & \multirow{2}{*}{$\begin{array}{l}\text { Structural indicators: } \\
\text { - the provisions regarding the RBVA can be more imprecise in terms of the surface types, the forms of vegetation or } \\
\text { structural and functional composition } \\
\text { - moreover, in order to enhance structural diversity of the greenspaces and green recreational areas, the specification of } \\
\text { the minimum RBVA can be supplemented with eco-spatial indices: BAF, SGF, GSF }\end{array}$} \\
\hline $\begin{array}{l}\text { - recommending minimum planting of RBVA with trees } \\
\text { or to cover all the vacant space with greenery in some } \\
\text { residential and waterfront areas }\end{array}$ & \\
\hline $\begin{array}{l}\text { - prohibition or restriction of locating advertising carriers } \\
\text { and high construction elements in the inner-city } \\
\text { and waterfront areas } \\
\text { - improving the visual attractiveness and of } \\
\text { infrastructural deficiencies (such as functional facilities } \\
\text { and lightning) of public spaces and greenspaces }\end{array}$ & \multirow{2}{*}{$\begin{array}{l}\text { Visual indicators: } \\
\text { - at the element level visual quality can be evaluated based on visual landscape preferences indicators } \\
\text { - however, they should be coupled with other indicators since the observers' interpretation may often be subjective }[29,76] \\
\text { - in case of the proposed high vegetation, it should be preceded by some visual analysis concerning composition } \\
\text { and visibility, e.g. indicators based on the digital panoramic view analysis }\end{array}$} \\
\hline $\begin{array}{l}\text { - requiring isolating greenery along major roads } \\
\text { and around protected areas as well as vegetation elements } \\
\text { to improve acoustic standards in residential areas }\end{array}$ & \\
\hline \multicolumn{2}{|l|}{ 2. Shape level—SCSDDM for Gdańsk and Poznań $[89,94]$} \\
\hline $\begin{array}{l}\text { - protecting the existing ecosystems: } \\
\text { (1) the Municipal System of Biologically Active Areas } \\
\text { in Gdańsk; } \\
\text { (2) the green wedges and rings system in Poznań }\end{array}$ & \multirow{3}{*}{$\begin{array}{l}\text { Ecological indicators: } \\
\text { - in order to monitor the identification, protection and transformation of landscape units, LM should be applied }\end{array}$} \\
\hline $\begin{array}{l}\text { - preserving the continuity of watercourses and existing } \\
\text { ecological connections with surrounding non-urban areas }\end{array}$ & \\
\hline - integration of the isolated green areas & \\
\hline
\end{tabular}


Table 2. Cont.

\begin{tabular}{|c|c|}
\hline $\begin{array}{l}\text { Existing Planning Instruments and Their Provisions } \\
\text { Regarding UL Management and the Delivery of UG }\end{array}$ & $\begin{array}{l}\text { Recommendations for Improving the Effectiveness of the Existing Instruments and Provisions by Means of LGI } \\
\text { in Terms of Sustainable Landscape Transformation }\end{array}$ \\
\hline $\begin{array}{l}\text { - improving the accessibility of the waterfront areas } \\
\text { and reconnecting them to the vital urban functional areas } \\
\text { and greenspaces }\end{array}$ & \multirow{3}{*}{$\begin{array}{l}\text { Structural indicators: } \\
\text { - the distribution of UG in each case should be preceded by an analysis of the accessibility standards: accessibility metrics } \\
\text { or ANGSt } \\
\text { - UNGI may be useful at the shape level in order to identify critical areas in terms of the amount and quality of UG } \\
\text { - at the level of particular neighborhoods [47] }\end{array}$} \\
\hline $\begin{array}{l}\text { - creating new ecological connections with surrounding } \\
\text { non-urban areas }\end{array}$ & \\
\hline $\begin{array}{l}\text { - improving the accessibility of UG through } \\
\text { the development of new parks and smaller green areas }\end{array}$ & \\
\hline $\begin{array}{l}\text { - identifying and protecting valuable natural habitats } \\
\text { with high biodiversity of species }\end{array}$ & \multirow{3}{*}{$\begin{array}{l}\text { Visual indicators: } \\
\text { - analysis of the visual perception and landscape composition at the level of the municipal system should be applied, } \\
\text { e.g., by means of visual landscape preferences indicators, indicators based on the digital panoramic views analysis } \\
\text { and landscape visual character indicators }\end{array}$} \\
\hline $\begin{array}{l}\text { - enhancing biodiversity of urban } \\
\text { ecological-visual systems }\end{array}$ & \\
\hline $\begin{array}{l}\text { - introducing the ratio of recreational greenspace for } \\
\text { residential areas }\end{array}$ & \\
\hline \multicolumn{2}{|c|}{$\begin{array}{l}\text { 3. Space level—SDPMA (SDPMA of Gdańsk, Gdynia and Sopot [95] and The Concept for Spatial Development for Metropolitan Area of Poznań [96]—A draft for the spatial } \\
\text { development plan) }\end{array}$} \\
\hline $\begin{array}{l}\text { - inventorying the existing system of landscape patches } \\
\text { and corridors of high natural values }\end{array}$ & \multirow{3}{*}{$\begin{array}{l}\text { Ecological indicators: } \\
\text { - some guidelines regarding the methods and instruments for evaluating the structure and character of the landscape units } \\
\text { and the dynamics of their transformation should be provided, e.g., LM } \\
\text { - some instruments can be suggested for the identification and preservation of landscape visual protection zones }\end{array}$} \\
\hline - defining the various forms of nature conservation & \\
\hline $\begin{array}{l}\text { - monitoring landscape changes, preserving natural or } \\
\text { semi-natural areas and the coherence and sustainability } \\
\text { of natural processes }\end{array}$ & \\
\hline $\begin{array}{l}\text { - designation of urbanization zones characterized by } \\
\text { different development directions } \\
\text { and development intensity }\end{array}$ & \multirow{2}{*}{$\begin{array}{l}\text { Structural indicators: } \\
\text { - LCVI may be suggested as it allows to evaluate the consistency and the forecasted changes in the provisions concerning } \\
\text { nature protection in spatial planning documents [48] }\end{array}$} \\
\hline $\begin{array}{l}\text { - recommending the creation of biologically active areas, } \\
\text { e.g., in the form of green rings around municipal areas, } \\
\text { and the implementation of new forms of greenery }\end{array}$ & \\
\hline $\begin{array}{l}\text { - protection of cultural landscape and identifying } \\
\text { the diversity of visual landscape values }\end{array}$ & $\begin{array}{l}\text { Visual indicators: } \\
\text { - at a larger, regional scale GLAM indicators are an applicable and cost-efficient tool, as they are calculated on a wide grid } \\
(0.25 \mathrm{~km}) \text { with the use of nationally available GIS data [79] }\end{array}$ \\
\hline
\end{tabular}


The English planning system was reformed and simplified with the assumption of transferring as many decisions to be made at the lowest possible level and with the participation of local communities. At the national level, the National Planning Policy Framework was established which must be taken into account in preparing Local Plans (LP) and Neighborhood Plans (NP) as well as during examining planning applications. Until recently, across local strategic planning was provided by means of Regional Strategies. However, in the current policy, a strong focus is placed on the competences of the local authorities and regional planning (realized by means of Regional Spatial Strategies) was abolished through the Localism Act 2011 (which extends to England and Wales). However, the cooperation between the administrative boundaries was maintained due to the 'Duty to Cooperate', which is also applied when the LPs are established. LPs are, in turn, the basis for the realization of all aspects of urban policy: housing, economy, social aspects, infrastructure and planning as well as environmental management. LP is developed for the entire area of the municipality, but the spatial strategies are divided into particular districts. Apart from LPs, neighborhood planning is also applied which is aimed at activating local communities in the planning process. Local communities can establish their own policies for the development of the area which supplement the provisions within the LP. The form or the scope of the NP is not strictly defined $[105,106]$.

In the city of Bristol, landscape planning is an important part of the municipal spatial policy and the impact of development proposals on landscape is taken into consideration. In the English planning system, NP corresponds with the element level and LP with the shape level. In Bristol, at the element level, due to the lack of NP for the study area, the Bristol Central Area Plan can be taken into consideration [107]. At the shape level, policies for the protecting, providing, enhancing and expanding the green infrastructure are included in the Bristol Development Framework Bristol Core Strategy (a part of the LP), which ensures the green infrastructure assets, type and amount. Within the LP the municipal Strategic Green Infrastructure is defined and certain indicators are proposed to evaluate whether the established targets are delivered [108]. More specific provisions are included in various supplementary plans and strategies. For example, the city has its Park's and Green Space Strategy which was developed as a contribution to the wider urban planning strategies in terms of the provision of high quality UL and UG [109]. Moreover, the Bristol Biodiversity Action Plan was developed to provide a framework for habitat and species conservation within the urban areas. It proposes the use of various indicators adopted from the England Biodiversity Strategy which are relevant to the city of Bristol (e.g., the biological quality of rivers, the number of community groups involved in practical wildlife projects, etc.) [110]. The accessibility indicators are also measured at the municipal level. It is estimated that in Bristol $88 \%$ of the residents live within the distance from greenspace proposed by Natural England standard (the rate is a little lower- $87 \%$ - for inner city areas due to a more compact development) [111], while in other cities in the UK this rate may even be less than $40 \%$ [104]. Regional planning is generally omitted in the English system as and more focus is placed on local planning. However, various regional partnerships can serve at the space level such as the West of England Partnership within which the Strategic Green Infrastructure Framework is developed [112].

\subsection{Visual, Ecological and Structural Quality of Urban Riverside Landscape-Case Studies}

In urban areas, river corridors play a crucial role in regulating ecological processes and urban local climate [113], but they also constitute a very distinctive element in the UL due to their unique character. The variability of the shape and profile of the river and the diversity of cover determines its visual attractiveness. The particular feature of riverside landscape is its extensive panoramas and views and the possibility to observe it from many different viewpoints, which provides a wide range of aesthetic sensations [85]. Therefore, spatial planning instruments should ensure the protection of both ecological and visual diversity for urban river landscapes. The issue of continuity and consistency of the natural and landscape structures is discussed based on three case studies of riverside landscapes in Bristol, Gdańsk and Poznań. River ecosystems are important dominants in the structure of the discussed cities, 
relevant for the continuity of their spatial structures; however, they were transformed by the process of urbanization to a different extent. Moreover, the local authorities' approach to the shaping of urban riverside landscapes in the three cities also varies.

The Bristol harbor side regeneration is an example of successful urban landscape management process in which a high quality of landscape composition and public accessibility of the water was pursued. This is partly due to the discussed UL and UG management strategies as well, as LGI existing in the planning system. However, many other factors also played an important role. For example, biologically diverse habitats were created and the visual connections between the waterfront and important urban dominants are preserved (by the creation of visual openings and compositional axes) $[88,114]$. The waterfront habitats and pedestrian paths in the harbor side areas in Bristol are depicted in Figures 4 and 5. These unique UL and UG structures were created due to the municipal policies, which is not always achieved in other cities in the UK. Reports are made that in the maintenance of the quality of UG is deteriorating due to limited funding. A distribution of responsibilities and the inclusion of various stakeholders in the process of UG creation and management might constitute a solution to this problem [115]. Moreover, the use of the proposed LGI framework to supplement the existing solutions could be also explored. However, it is important to underline that these two discussed planning systems vary in terms of structure and procedures, so it would require further extensive research and taking into consideration many local and legal conditions.

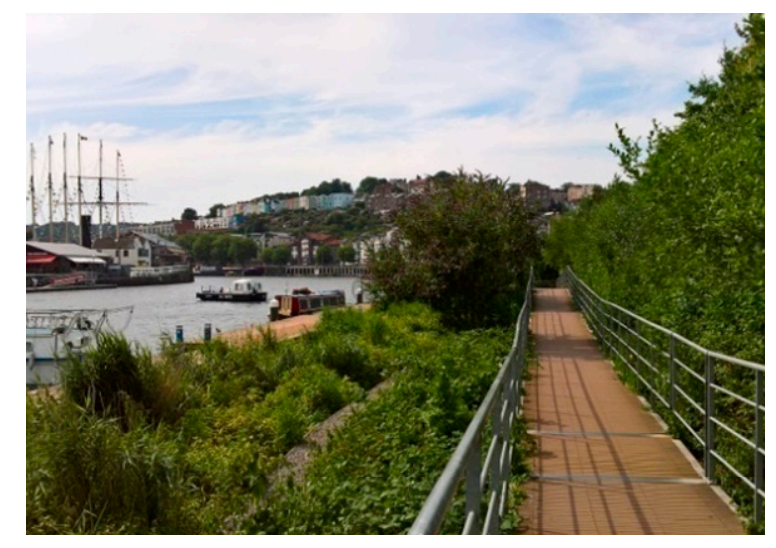

Figure 4. The development of the riverside landscape in Bristol: waterfront habitats and pedestrian paths.

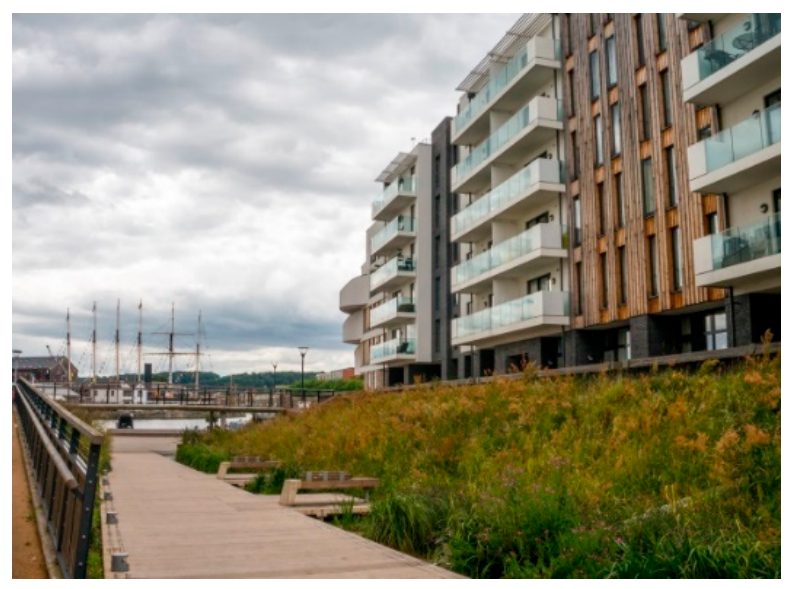

Figure 5. The development of the riverside landscape in Bristol: waterfront habitats and pedestrian paths.

The waterfront in Gdańsk is a distinctive element of the city landscape and its ecological balance. Despite some important strategic provisions regarding the coherent urban development, there is still a lack of efficient policies in vital areas and instruments limiting suburbanization in Gdańsk by 
the process of reurbanization of its central area. To successfully revitalize the inner city, fresh urban strategies are needed [116] as the planning actions undertaken in Gdańsk are contemporary and not taking into consideration the whole urban system. On the one hand, attractive housing development are created by the waterfront. On the other hand, public accessibility of the waterfront is still limited. Moreover, the lack of visual connections as well as the replicability and monotony of compositional elements decrease landscape and structural visual quality (as depicted in Figures 6 and 7).

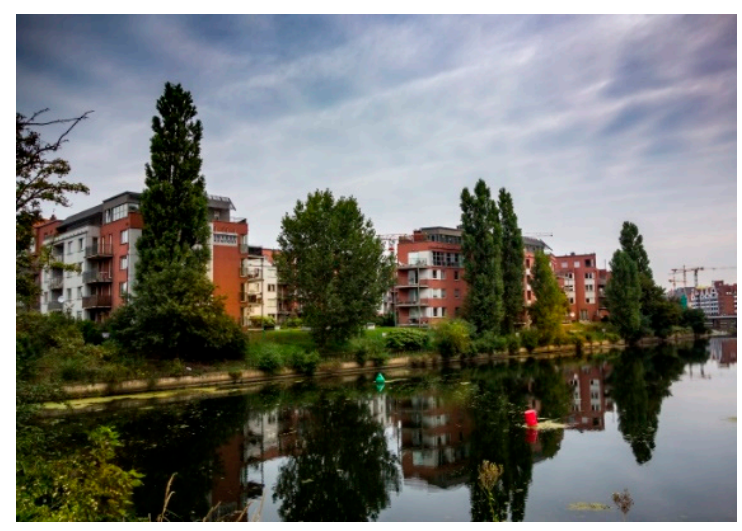

Figure 6. Gdańsk-new residential developments near the Motława Channel.

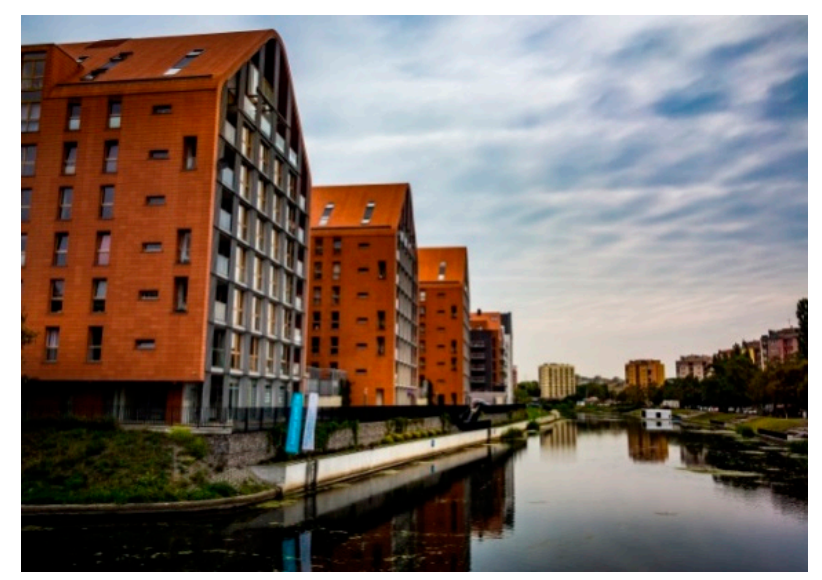

Figure 7. Gdańsk—new residential developments near the Motława Channel.

In Poznan, the regeneration strategy of the Warta river waterfront has been discussed over the past decades; however, it is still not implemented in a comprehensive way. Despite many social initiatives regarding the revitalization of the riverside area, its landscape becomes increasingly fragmented due to individual LSDP for the areas which are attractive for the developers [93]. The planning decisions regarding the location and parameters of new developments are not preceded by visual analysis based on adequate methods and indicators. Landscape structures constitute a foreground for the exposition for important urban dominants and landmarks and extensive biologically active areas (as depicted in Figure 8), but in certain places, due to visual barriers, there is a lack of visual connection with the riverside landscape (Figure 9). 


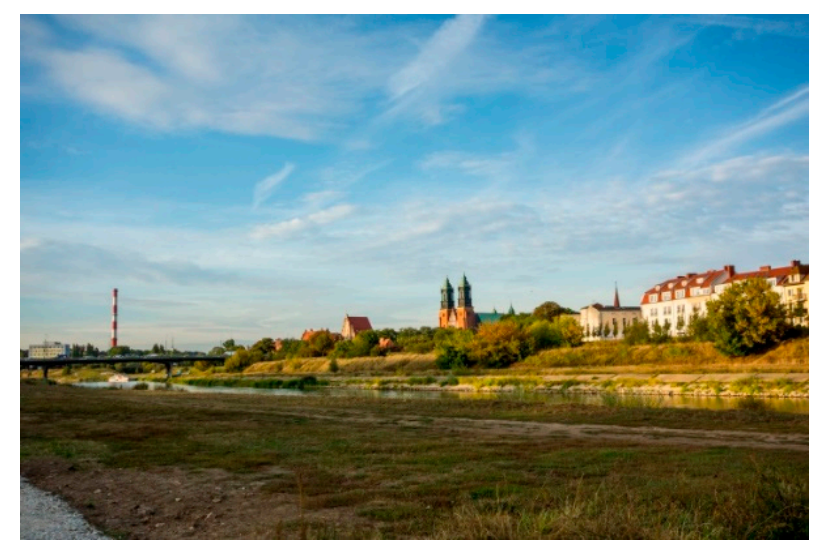

Figure 8. Warta waterfront in Poznań: the open view on the cathedral complex.

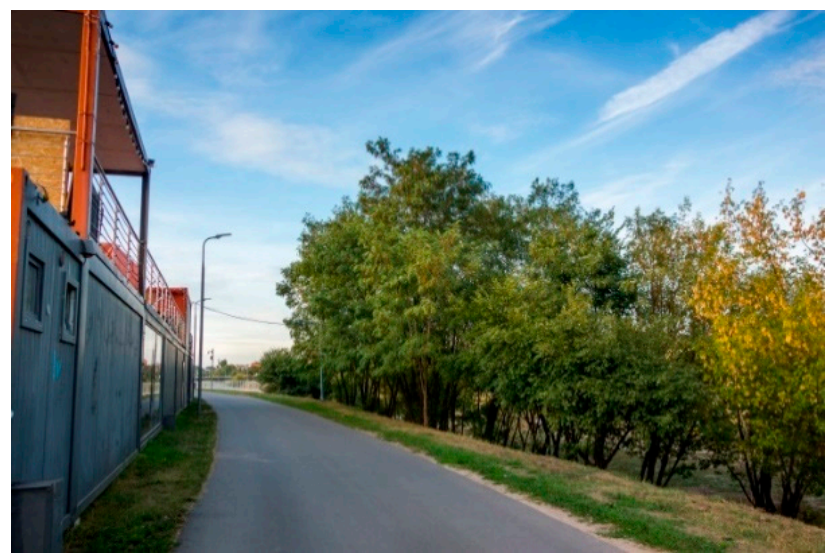

Figure 9. Warta waterfront in Poznań: visual barriers near the city beach.

Both in Gdańsk and in Poznan, there is a lack of consistency between spatial planning and holistic waterfront landscape management, recognized in ecological, structural and visual dimension. The common practice of establishing LSDP for relatively small areas leads to the landscape and fragmentation and disintegration. This is a consequence of the Polish spatial planning system-its legal basis and procedures. However, initiatives undertaken by the local authorities in Gdańsk and Poznań indicate that waterfront landscape and greenspace management might in the future be reintegrated at a municipal level. A regeneration plan for the redevelopment of Motława Channel waterfront was recently announced, developed by the City of Gdańsk Development Office and mainly aimed at improving the pedestrian accessibility. In Poznań next steps are undertaken to finalize and to implement assumptions of the regeneration strategy of the Warta river waterfront.

The quality of the urban riverside landscape for the three analyzed case studies in Bristol, Poznań and Gdańsk can be evaluated by means of the selected ecological, structural and visual LGI indicators. Given the scale of the specified research areas, LGI applicable at the element and shape level will be especially useful (see Table 2). They are compatible with this level of the planning system and the content of the planning documents prepared for such urban structures. The element level indicators allow to describe and evaluate particular elements (natural and built-up) as well as their distribution, composition and mutual relation at the local scale. Shape level indicators, on the other hand, are useful to analyze and evaluate more complex spatial structures consisting of numerous elements (such as areas characterized by heterogeneous features and intensity of development or green areas varied in terms of the degree of their naturalness and greenery forms). To evaluate the specified research areas, space level indicators are not directly applicable. However, it is important to include guidelines resulting from the space level analysis at the local scale, especially in terms of the continuity of the ecological systems, composition of landscape structures or the protection of exposition zones. 
It is also important to note that LGI is a tool to inform the process of urban planning and to deliver useful information about the existing as well as forecast ecological, structural and visual landscape features. However, it should be underlined that they do not provide ready solutions for landscape transformation. They rather constitute a set of data which should be considered alongside other factors. Similarly, various environmental quality evaluation tools should also serve only as an aid in the process of horizontal decision-making, developed with the participation of the local community, in which other conditions are also taken into account [15]. A more horizontal network approach, in which various stakeholders are included, is becoming increasingly recognized rather than a top-down one, as a more appropriate mode of decision making to address the complexity of urban development (which is often referred to as the shift from government to governance) [117-119]. This shift, which also implies the need to coordinate between various stakeholders and resources, has very serious implications for the science-based practice of landscape planning and management, as it was underlined by Beuen and Opdam [120]. They broadly discussed the role of research and substantial knowledge in local landscape planning and highlighted that successful solutions are only developed in cooperation between scientists and practitioners, although finding the relationship between scientific and local knowledge is very challenging. Moreover, other actors such as the citizens and local non-governmental organizations also become informants in this process. Thus, many social aspects add to the landscape transformation debate such as human culture and behavior [121].

As UL is very often the only mean by which the residents come in contact with the environment, it seems particularly important to develop novel tools for its transformation and protection which will account for the social, economic, political as well as technological complexity of urbanization. However, in this process the social-ecological perspective is often neglected [122]. Therefore, it seems particularly important to address the issue of social participation in landscape governance in Poland with the use of LGI in future studies. The participatory aspect of urban landscape governance was one of the key aspects in successful landscape transformation and the development of the Bristol Harbourside Masterplan. This supported the creation of the sequence of public spaces and routes, connected with landscape features, habitats and visual connections between the riverside landscape and the urban tissue, which are frequently used by the inhabitants $[16,88,114]$. Social participation in landscape governance is also a part of a broader sustainable planning approach in Great Britain, although the means of integrated landscape management, which may encourage the involved stakeholders to more holistic thinking, still need to be further developed [123].

\section{Conclusions}

Urbanized areas are characterized by different types of landscape and open sites, given their high degree of environmental transformation and distinctive spatial and ecological features. Despite the intense urban development and the loss of natural areas, the cultural and ecological structures are interconnected. However, the continuing degradation of natural resources, shrinking biodiversity and landscape fragmentation require the use of effective planning and spatial management measures. The application of LGI in investigating, monitoring and evaluating urban landscape is increasingly often underlined.

In the article, an overview of LGI is conducted which are relevant in the process of planning and management of urban areas. Three groups of indicators are identified: ecological, structural and visual, which vary in terms of the theoretical and methodological approach as well as research tools. Particular indicators are adapted to the characterization, analysis, evaluation and monitoring of urban landscape. The selection of LGI should be always conducted in accordance with the context and the aim of the research as well as the scale and character of the study area. A holistic approach in which various aspects of urban landscape are included is essential to the development of sustainable urban structures. Such an approach should also account for the QoL as well as health of the residents, which are linked to the quality of landscape, the spatial distribution and the accessibility of greenspace. This aspect is often included in current sustainable urban development strategies and underlined in academic research. The features of biodiversity and ecosystem stability, continuity and diversification 
of spatial structures as well as composition, visual attractiveness and accessibility can determine landscape quality. In the article, an integrated approach towards the application of landscape indicators in urban planning is tackled. Based on three case studies in Bristol, Gdańsk and Poznań, it is shown that various spatial planning tools, resulting from the specifics of the English and Polish planning systems, may impact the quality of urban landscape. The analysis of the planning documents in Gdańsk and Poznań in terms of UL and UG management allowed to formulate recommendations for improving the effectiveness of the existing provisions with the use of ecological, structural and visual LGI.

Based on the analysis of the three case studies, it can be concluded that there is a considerable diversity among the adopted evaluation criteria for the riverside UL and UG (regarding its biodiversity, view extent, attractiveness and accessibility). This results from various approaches towards landscape management in the spatial policy of the discussed countries and cities, the scope of the planning documents and development studies, as well as from the applied indicators and methods for landscape evaluation. The following conclusions can be synthesized:

1. The regeneration of the river Avon waterfront in Bristol was based on a coherent landscape plan. The included pro-ecological and landscape-beneficial solutions were preceded by visual and compositional analysis. In result, the transformed urban space is characterized by high visual value and biodiversity and it is fully accessible to the residents.

2. In case of the Motława Channel waterfront in Gdańsk, there was no overall landscape project, although the protection of the continuity and consistency of landscape is advocated in the SCSDDM. Due to several LSDP for the area, the landscape is becoming increasingly fragmented and the continuity of the natural structures is interrupted. The waterfront is densely built-up, the proportion of green areas and their accessibility are relatively low and there are limited visual connections.

3. The area of Warta river valley in Poznań is covered by a regeneration program which is aimed at the restoration of the ecological and compositional continuity and the improvement of the waterfront accessibility. However, this is a conceptual project, so the development of the waterfront is still based on several LSDP. The accessibility of the waterfront is relatively high (except some built-up zones), yet, the degree of biodiversity is quite low. Due to the lack of visual analysis, there are some limitations in the visual connections.

Due to their rising number and great diversification, it is necessary to select indicators which are useful and applicable in the Polish spatial planning system. Based on the conducted study it can be expected that integrating various types of LGI within Polish planning instruments will allow for a more effective evaluation, protection and creation of biologically active areas and visual structures in the urban tissue. It will also allow for the determination of the actual potential of these areas and structures in the creation of sustainable UL and UG. The preselected ecological, structural and visual LGI are assigned to the existing Polish urban planning and spatial management instruments at various scales, which constitutes a basis for methodological and theoretical development in further studies. In-depth analysis of several factors should be subjected to further research, including the comparability and applicability of LGI, the possibility of their mapping and the accessibility of data, legal aspects and the capacity of adapting to the changes in the landscape management system. The above conclusions result from preliminary research conducted within the selected study areas. Direct application of the LGI framework at the various levels of Polish planning system and in specific urban planning documents is proposed. However, the so-far collected materials suggest that further investigation into the integration of LGI within the Polish spatial planning system is needed. Developing the framework as well as considering its applicability for other planning systems should be considered in future studies. It is also acknowledged that there are limitations of this research resulting from the limited number of conducted case studies. Therefore, extending the research to other urban areas is recommended. Moreover, another prospect for further research is also to investigate in greater detail the governance implications of the proposed LGI. As discussed in the article, LGI do not provide ready solutions 
for landscape transformation but they rather constitute a set of data which may serve as an aid in participatory governance and landscape management, making these processes more effective.

In the article, an indicator-based approach towards the process of sustainable urban planning and decision-making is sought in terms of UL and UG transformation. It is aimed at addressing many aspects of this transformation: protecting and enhancing the visual, ecological and structural quality of landscape as well as improving the QoL of the urban residents. Given the complexity and multidimensionality of all these aspects, it may be often difficult to achieve their integration only by means of the existing planning instruments, as it is discussed for the presented case studies. Therefore, it is argued that the developed LGI framework should be applied in practical terms to supplement the current planning system and that it can support the improvement of health and well-being by suitable UL and UG transformation. The application of the proposed set of LGI may result in more effective planning decisions adjusted to the local context. Bringing the three aforementioned aspects together can help in the formulation of a more holistic urban policy in terms of UL and UG management.

The proposed LGI framework constitutes a novel method for the long-term evaluation of greenspaces for the purpose of urban planning. Its application should be considered both at the level of single investments as well as local and municipal planning documents (from LSDP and NP, SCSDDM and LP, to SDPMA and documents from other planning systems accordingly), as discussed in the article. However, the reasons why it may be useful for various other specific roles in local urban governance networks should be also taken into consideration. From the point of view of urban policy decision makers, LGI indicators may serve as a tool to support formulating integrated strategies for urban development. For example, in the development of the waterfront in Gdańsk the accessibility factor was not taken into account, whereas in Poznan visual connectivity with the riverside landscape was neglected in some locations. Therefore, it is argued that the proposed LGI may facilitate combining all relevant features of UL and UG transformation and it may be useful in the development of various urban policies (such as the Bristol's Park and Green Space Strategy and other strategies for urban greenery systems). For environmentalists and conservationists, the LGI framework may prove to be helpful for the purpose of monitoring the current state of urban ecosystems and protecting ecological processes and biodiversity within urban development strategies (e.g., within various environmental protection plans for urban areas or other tools aimed at evaluating environmental impact and implications of planning decisions). For architects and designers, the LGI can help to account for attractiveness and visual perception of UL and UG in specific projects. Finally, from the point of view of social stakeholders, it should be useful for providing data and informing the process of urban decision-making in a more horizontal, network governance approach (e.g., the proposed LGI can be used in public consultations to illustrate the current structure and quality of UL and UG, to indicate areas for improvements and to discuss greenspace development strategies). The importance of social participation in UL and UG landscape transformation is illustrated by the Bristol case study.

In the article, the importance of greenspaces and its various features is also discussed in relation to human health and wellbeing in order to present new understanding of the importance of sustainable urban planning which takes into account the quality of urban greenspaces. Multiple benefits from UL and UG management are presented, as well as the way they should be integrated into urban planning and spatial management of cities. UL and UG constitute an important factor in the protection of biodiversity in urban areas and provide ecosystem services. Moreover, they play a crucial role in the improvement of both physical health, by ensuring the contact with the natural environment, as well as mental health and well-being, by providing space for various leisure, sport or social activities. Urban landscape also provides open space and visual sensations which are important from the point of view of behavioral psychology and cultural geography. As mentioned before, urban greenspaces often provide the only contact of the residents with nature. Therefore, it is important that their distribution and proportions within residential developments in the city are well planned for. 
Therefore, the mental health and well-being of the residents can be improved by increasing the availability of open spaces within the city area and some of the structural indicators can successfully serve this purpose. Visual indictors are also useful from that point of view, especially given that the perception and preference aspects can improve perceived access, as discussed in the article. Therefore, the proposed LGI can be considered to supplement the formulation of municipal housing policies (such as the referenced Warsaw Housing Standard or other similar documents) in terms of UL and UG transformation aimed at improving the QoL of the residents. It may be also very useful for the municipal greenspaces development standards which are currently being established in Poland. Moreover, other aspects can also be taken into consideration with regard to human health and well-being such as the role of greenspaces in the improvement of urban air quality, which is currently a widely discussed topic among academics from many fields. This may be achieved to some extent by the appropriate proportion, distribution and composition of urban greenery within the city area and to this end, the application of the proposed LGI framework can also be considered (e.g., in the formulation of urban greenery strategies in municipal air protection programs). However, the proposed practical implications should be regarded as preliminary indications rather than robust empirical results. The aforementioned aspects connected with the applicability of the proposed LGI framework should be subjected to further detailed consideration in future studies.

Author Contributions: Conceptualization, J.B. and E.R.; Methodology, J.B. and E.R.; Investigation, J.B. and E.R.; Writing—original draft preparation, J.B.; Writing—review and editing, J.B. and E.R.; Visualization, J.B.

Funding: This research was founded from statutory funds of Gdańsk University of Technology, Faculty of Architecture and University of the Arts in Poznań, Faculty of Architecture and Design.

Conflicts of Interest: The authors declare no conflict of interest.

\section{References}

1. Yigitcanlar, T.; Teriman, S. Rethinking sustainable urban development: towards an integrated planning and development process. Int. J. Environ. Sci. Technol. 2015, 12, 341-352. [CrossRef]

2. Ioppolo, G.; Cucurachi, S.; Salomone, R.; Saija, G.; Shi, L. Sustainable Local Development and Environmental Governance: A Strategic Planning Experience. Sustainability 2016, 8, 180. [CrossRef]

3. Alberti, M.; Waddell, P. An integrated urban development and ecological simulation model. Integr. Assess. 2000, 1, 215-227. [CrossRef]

4. Hostetler, M.; Allen, W.; Meurk, C. Conserving urban biodiversity? Creating green infrastructure is only the first step. Landsc. Urban Plan. 2011, 100, 369-371. [CrossRef]

5. Grêt-Regamey, A.; Altwegg, J.; Sirén, E.A.; van Strien, M.J.; Weibel, B. Integrating ecosystem services into spatial planning-A spatial decision support tool. Landsc. Urban Plan. 2017, 165, 206-219. [CrossRef]

6. Abraham, A.; Sommerhalder, K.; Abel, T. Landscape and well-being: A scoping study on the health-promoting impact of outdoor environments. Int. J. Public Health 2010, 55, 59-69. [CrossRef]

7. Velarde, M.D.; Fry, G.; Tveit, M. Health effects of viewing landscapes-Landscape types in environmental psychology. Urban For. Urban Green. 2007, 6, 199-212. [CrossRef]

8. Wolch, J.R.; Byrne, J.; Newell, J.P. Urban green space, public health, and environmental justice: The challenge of making cities "just green enough". Landsc. Urban Plan. 2014, 125, 234-244. [CrossRef]

9. Tzoulas, K.; Korpela, K.; Venn, S.; Yli-Pelkonen, V.; Kaźmierczak, A.; Niemela, J.; James, P. Promoting ecosystem and human health in urban areas using Green Infrastructure: A literature review. Landsc. Urban Plan. 2007, 81, 167-178. [CrossRef]

10. Gavrilidis, A.A.; Ciocănea, C.M.; Niţă, M.R.; Onose, D.A.; Năstase, I.I. Urban Landscape Quality Index—Planning Tool for Evaluating Urban Landscapes and Improving the Quality of Life. Procedia Environ. Sci. 2016, 32, 155-167. [CrossRef]

11. Kowarik, I. Novel urban ecosystems, biodiversity, and conservation. Environ. Pollut. 2011, 159, 1974-1983. [CrossRef]

12. Loures, L. Post-industrial landscapes as drivers for urban redevelopment: Public versus expert perspectives towards the benefits and barriers of the reuse of post-industrial sites in urban areas. Habitat Int. 2015, 45, 72-81. [CrossRef] 
13. Runhaar, H.; Driessen, P.P.J.; Soer, L. Sustainable urban development and the challenge of policy integration: An assessment of planning tools for integrating spatial and environmental planning in the Netherlands. Environ. Plan. B Plan. Des. 2009, 36, 417-431. [CrossRef]

14. Ahern, J. Urban landscape sustainability and resilience: The promise and challenges of integrating ecology with urban planning and design. Landsc. Ecol. 2013, 28, 1203-1212. [CrossRef]

15. Badach, J.; Kolasińska, P.; Paciorek, M.; Wojnowski, W.; Dymerski, T.; Gębicki, J.; Dymnicka, M.; Namieśnik, J. A case study of odour nuisance evaluation in the context of integrated urban planning. J. Environ. Manag. 2018, 213, 417-424. [CrossRef]

16. Raszeja, E.; Badach, J. Urban space recovery. Landscape-beneficial solutions in new estates built in post-industrial and post-military areas in Bristol, Poznań and Gdańsk. Misc. Geogr. 2018, 22, 210-218. [CrossRef]

17. Steiner, F. Landscape ecological urbanism: Origins and trajectories. Landsc. Urban Plan. 2011, 100, $333-337$. [CrossRef]

18. Tress, G.; Tress, B.; Fry, G. Analysis of the barriers to integration in landscape research projects. Land Use Policy 2007, 24, 374-385. [CrossRef]

19. Bürgi, M.; Ali, P.; Chowdhury, A.; Heinimann, A.; Hett, C.; Kienast, F.; Mondal, M.K.; Upreti, B.R.; Verburg, P.H. Integrated Landscape Approach: Closing the Gap between Theory and Application. Sustainability 2017, 9, 1371. [CrossRef]

20. Hiremath, R.B.; Balachandra, P.; Kumar, B.; Bansode, S.S.; Murali, J. Indicator-based urban sustainability-A review. Energy Sustain. Dev. 2013, 17, 555-563. [CrossRef]

21. Lowry, J.H.; Lowry, M.B. Comparing spatial metrics that quantify urban form. Comput. Environ. Urban Syst. 2014, 44, 59-67. [CrossRef]

22. Vanderhaegen, S.; Canters, F. Mapping urban form and function at city block level using spatial metrics. Landsc. Urban Plan. 2017, 167, 399-409. [CrossRef]

23. Liu, M.; Hu, Y.M.; Li, C.L. Landscape metrics for three-dimensional urban building pattern recognition. Appl. Geogr. 2017, 87, 66-72. [CrossRef]

24. Zhao, C.; Fu, G.; Liu, X.; Fu, F. Urban planning indicators, morphology and climate indicators: A case study for a north-south transect of Beijing, China. Build. Environ. 2011, 46, 1174-1183. [CrossRef]

25. Fry, G.; Tveit, M.S.; Ode, A.; Velaverde, M.D. The ecology of visual landscapes: Exploring the conceptual common ground of visual and ecological landscape indicators. Ecol. Indic. 2009, 9, 933-947. [CrossRef]

26. Llausàs, A.; Nogué, J. Indicators of landscape fragmentation: The case for combining ecological indices and the perceptive approach. Ecol. Indic. 2012, 15, 85-91. [CrossRef]

27. Antrop, M. From holistic landscape synthesis to transdisciplinary landscape management. In From Landscape Research to Landscape Planning: Aspects of Integration, Education and Application; Tress, B., Tress, G., Fry, G., Opdam, P., Eds.; Springer: Dordrecht, The Netherlands, 2005; pp. 27-50.

28. Botequilha Leitão, A.; Ahern, J. Applying landscape ecological concepts and metrics in sustainable landscape planning. Landsc. Urban Plan. 2002, 59, 65-93. [CrossRef]

29. Wang, R.; Zhao, J.; Liu, Z. Consensus in visual preferences: The effects of aesthetic quality and landscape types. Urban For. Urban Green. 2016, 20, 210-217. [CrossRef]

30. Uuemaa, E.; Mander, Ü.; Marja, R. Trends in the use of landscape spatial metrics as landscape indicators: A review. Ecol. Indic. 2013, 28, 100-106. [CrossRef]

31. Uuemaa, E.; Antrop, M.; Roosaare, J.; Marja, R.; Mander, Ü. Landscape Metrics and Indices: An Overview of Their Use in Landscape Research. Living Rev. Landsc. Res. 2009, 3, 1-28. [CrossRef]

32. Aguilera, F.; Valenzuela, L.M.; Botequilha-Leitão, A. Landscape metrics in the analysis of urban land use patterns: A case study in a Spanish metropolitan area. Landsc. Urban Plan. 2011, 99, 226-238. [CrossRef]

33. Pham, H.M.; Yamaguchi, Y.; Bui, T.Q. A case study on the relation between city planning and urban growth using remote sensing and spatial metrics. Landsc. Urban Plan. 2011, 100, 223-230. [CrossRef]

34. Ramachandra, T.V.; Bharath, A.H.; Sowmyashree, M.V. Monitoring urbanization and its implications in a mega city from space: Spatiotemporal patterns and its indicators. J. Environ. Manag. 2015, 148, 67-81. [CrossRef]

35. Zhou, W.; Huang, G.; Cadenasso, M.L. Does spatial configuration matter? Understanding the effects of land cover pattern on land surface temperature in urban landscapes. Landsc. Urban Plan. 2011, 102, 54-63. [CrossRef] 
36. McCarty, J.; Kaza, N. Urban form and air quality in the United States. Landsc. Urban Plan. 2015, 139, 168-179. [CrossRef]

37. owicki, D. Landscape pattern as an indicator of urban air pollution of particulate matter in Poland. Ecol. Indic. 2019, 97, 17-24. [CrossRef]

38. Weber, N.; Haase, D.; Franck, U. Assessing modelled outdoor traffic-induced noise and air pollution around urban structures using the concept of landscape metrics. Landsc. Urban Plan. 2014, 125, 105-116. [CrossRef]

39. Whitford, V.; Ennos, A.R.; Handley, J.F. "City form and natural process"-Indicators for the ecological performance of urban areas and their application to Merseyside, UK. Landsc. Urban Plan. 2001, 57, 91-103. [CrossRef]

40. Lustig, A.; Stouffer, D.B.; Roigé, M.; Worner, S.P. Towards more predictable and consistent landscape metrics across spatial scales. Ecol. Indic. 2015, 57, 11-21. [CrossRef]

41. Hermy, M.; Cornelis, J. Towards a monitoring method and a number of multifaceted and hierarchical biodiversity indicators for urban and suburban parks. Landsc. Urban Plan. 2000, 49, 149-162. [CrossRef]

42. Solon, J. Sustainable landscape evaluation-In search of new ndicators [in Polish]. In Ecological-Landscape Studies in the Programing of Sustainable Development. Overview of Polish Experiences at the Verge of Integration with the European Union. [in Polish]; Kistowski, M., Ed.; University of Gdańsk: Gdańsk, Poland, 2004; pp. 49-58.

43. Szulczewska, B.; Giedych, R.; Borowski, J.; Kuchcik, M.; Sikorski, P.; Mazurkiewicz, A.; Stańczyk, T. How much green is needed for a vital neighbourhood? In search for empirical evidence. Land Use policy 2014, 38, 330-345. [CrossRef]

44. Senate Department for the Environment Transport and Climate Protection A Green City Center-BAF-Biotope Area Factor. Available online: https://www.berlin.de/senuvk/umwelt/landschaftsplanung/bff/index_en.shtml (accessed on 28 October 2018).

45. Seattle Department of Construction \& Inspections Seattle Green Factor. Available online: http://www.seattle. gov/sdci/codes/codes-we-enforce-(a-z)/seattle-green-factor (accessed on 28 October 2018).

46. Kruuse, A. GRaBS (Green and Blue Space Adaptation for Urban Areas and Eco Towns) Expert Paper 6: The Green Space Factor and the Green Points System; Town and Country Planning Association: London, UK, 2011.

47. Gupta, K.; Kumar, P.; Pathan, S.K.; Sharma, K.P. Urban Neighborhood Green Index-A measure of green spaces in urban areas. Landsc. Urban Plan. 2012, 105, 325-335. [CrossRef]

48. Gałecka-Drozda, A.; Raszeja, E.; Szczepańska, M.; Wilkaniec, A. Land Cover Changes in Natura 2000 Areas Located in Suburban Zones: Planning Problems in the Context of Environmental Protection. Polish J. Environ. Stud. 2018, 28, 1-9. [CrossRef]

49. Hanley, N.; Ready, R.; Colombo, S.; Watson, F.; Stewart, M.; Bergmann, E.A. The impacts of knowledge of the past on preferences for future landscape change. J. Environ. Manage. 2009, 90, 1404-1412. [CrossRef]

50. Handley, J.; Pauleit, S.; Slinn, P.; Barber, A.; Baker, M.; Jones, C.; Lindley, S. Accesible Natural Green Space. Standards in towns and cities: A review and toolkit for their implementation. Report Number 526; Natural England: Peterborough, England, 2003.

51. Natural England. 'Nature Nearby' Accessible Natural Greenspace Guidance; Thompson, G., Ed.; Natural England: Sheffield, UK, 2010.

52. Moseley, D.; Marzano, M.; Chetcuti, J.; Watts, K. Green networks for people: Application of a functional approach to support the planning and management of greenspace. Landsc. Urban Plan. 2013, 116, 1-12. [CrossRef]

53. La Rosa, D. Accessibility to greenspaces: GIS based indicators for sustainable planning in a dense urban context. Ecol. Indic. 2014, 42, 122-134. [CrossRef]

54. Rojas, C.; Páez, A.; Barbosa, O.; Carrasco, J. Accessibility to urban green spaces in Chilean cities using adaptive thresholds. J. Transp. Geogr. 2016, 57, 227-240. [CrossRef]

55. Wang, D.; Brown, G.; Liu, Y.; Mateo-Babiano, I. A comparison of perceived and geographic access to predict urban park use. Cities 2015, 42, 85-96. [CrossRef]

56. Wan, C.; Shen, G.Q. Encouraging the use of urban green space: The mediating role of attitude, perceived usefulness and perceived behavioural control. Habitat Int. 2015, 50, 130-139. [CrossRef]

57. Verbič, M.; Slabe-Erker, R.; Klun, M. Contingent valuation of urban public space: A case study of Ljubljanica riverbanks. Land use policy 2016, 56, 58-67. [CrossRef]

58. Gobster, P.H.; Nassauer, J.I.; Daniel, T.C.; Fry, G. The shared landscape: What does aesthetics have to do with ecology? Landsc. Ecol. 2007, 22, 959-972. [CrossRef] 
59. Committee of Ministers of the Council of Europe. European Landscape Convention; Council of Europe: Florence, Italy, 2000.

60. Daniel, T.C. Whither scenic beauty? Visual landscape quality assessment in the 21st century. Landsc. Urban Plan. 2001, 54, 267-281. [CrossRef]

61. Tveit, M.S. Indicators of visual scale as predictors of landscape preference; a comparison between groups. J. Environ. Manag. 2009, 90, 2882-2888. [CrossRef]

62. Raszeja, E.; Mikulski, D. Integrated assessment of social value of landscape in the Środa Wielkopolska Region. Sp. Form 2016, 26, 145-162.

63. Nijhuis, S.; van Lammeren, R.; Antrop, M. Exploring the visual landscape. In Exploring the Visual Landscape. Advances in Physiognomic Landscape Research in The Netherlands.; Nijhuis, S., Van Lammeren, R., Van Der Hoeven, F.D., Eds.; IOS Press, Delft University of Technology: Delft, The Netherlands, 2011.

64. Hernández, J.; García, L.; Ayuga, F. Assessment of the visual impact made on the landscape by new buildings: A methodology for site selection. Landsc. Urban Plan. 2004, 68, 15-28. [CrossRef]

65. Rodrigues, M.; Montañés, C.; Fueyo, N. A method for the assessment of the visual impact caused by the large-scale deployment of renewable-energy facilities. Environ. Impact Assess. Rev. 2010, 30, 240-246. [CrossRef]

66. Molina-Ruiz, J.; Martínez-Sánchez, M.J.; Pérez-Sirvent, C.; Tudela-Serrano, M.L.; García Lorenzo, M.L. Developing and applying a GIS-assisted approach to evaluate visual impact in wind farms. Renew. Energy 2011, 36, 1125-1132. [CrossRef]

67. Samavatekbatan, A.; Gholami, S.; Karimimoshaver, M. Assessing the visual impact of physical features of tall buildings: Height, top, color. Environ. Impact Assess. Rev. 2016, 57, 53-62. [CrossRef]

68. Hehl-Lange, S.; Lange, E. Virtual environments. In Research in Landscape Architecture Methods and Methodology; van den Brink, A., Bruns, E., Tobi, H., Bell, S., Eds.; Routledge Taylor \& Francis Group: London, UK; New York, NY, USA, 2017; pp. 161-178.

69. Ozimek, P.; Bohm, A.; Ozimek, A.; Wańkowicz, W. Planning for Space of High Landscape Values Using Digital Site Analysis and Economic Evaluation [in Polish]; Cracow University of Tehcnology: Cracow, Poland, 2013.

70. Bishop, I.D. Assessment of Visual Qualities, Impacts, and Behaviours, in the Landscape, by Using Measures of Visibility. Environ. Plan. B Plan. Des. 2003, 30, 677-688. [CrossRef]

71. De Groot, R. Function-analysis and valuation as a tool to assess land use conflicts in planning for sustainable, multi-functional landscapes. Landsc. Urban Plan. 2006, 75, 175-186. [CrossRef]

72. Plexida, S.G.; Sfougaris, A.I.; Ispikoudis, I.P.; Papanastasis, V.P. Selecting landscape metrics as indicators of spatial heterogeneity-A comparison among Greek landscapes. Int. J. Appl. Earth Obs. Geoinf. 2014, 26, 26-35. [CrossRef]

73. Fan, C.; Myint, S. A comparison of spatial autocorrelation indices and landscape metrics in measuring urban landscape fragmentation. Landsc. Urban Plan. 2014, 121, 117-128. [CrossRef]

74. Apparicio, P.; Abdelmajid, M.; Riva, M.; Shearmur, R. Comparing alternative approaches to measuring the geographical accessibility of urban health services: Distance types and aggregation-error issues. Int. J. Health Geogr. 2008, 7, 7. [CrossRef] [PubMed]

75. Fan, P.; Xu, L.; Yue, W.; Chen, J. Accessibility of public urban green space in an urban periphery: The case of Shanghai. Landsc. Urban Plan. 2017, 165, 177-192. [CrossRef]

76. Dramstad, W.E.; Tveit, M.S.; Fjellstad, W.J.; Fry, G.L.A. Relationships between visual landscape preferences and map-based indicators of landscape structure. Landsc. Urban Plan. 2006, 78, 465-474. [CrossRef]

77. Ode, Å; Fry, G.; Tveit, M.S.; Messager, P.; Miller, D. Indicators of perceived naturalness as drivers of landscape preference. J. Environ. Manag. 2009, 90, 375-383. [CrossRef] [PubMed]

78. Frank, S.; Fürst, C.; Koschke, L.; Witt, A.; Makeschin, F. Assessment of landscape aesthetics-Validation of a landscape metrics-based assessment by visual estimation of the scenic beauty. Ecol. Indic. 2013, 32, $222-231$. [CrossRef]

79. Roos-Klein Lankhorst, J.; de Vries, S.; Buijs, A. Mapping landscape attractiveness-A GIS-based landscape appreciation model for the Durch countryside. In Exploring the Visual Landscape. Advances in Physiognomic Landscape Research in the Netherlands; Nijhuis, S., Van Lammeren, R., Van Der Hoeven, F.D., Eds.; IOS Press, Delft University of Technology: Delft, The Netherlands, 2011.

80. Tveit, M.; Ode, Å.; Fry, G. Key concepts in a framework for analysing visual landscape character. Landsc. Res. 2006, 31, 229-255. [CrossRef] 
81. Ode, Å.; Tveit, M.; Fry, G. Capturing landscape visual character using indicators: Touching base with landscape aesthetic theory. Landsc. Res. 2008, 33, 89-117. [CrossRef]

82. Jessel, B. Elements, characteristics and character-Information functions of landscapes in terms of indicators. Ecol. Indic. 2006, 6, 153-167. [CrossRef]

83. Ndubisi, F. Ecological planning: A Historical and Comparative Synthesis; John Hopkins University Press: Baltimore, USA, 2002.

84. Daniels, B.; Zaunbrecher, B.S.; Paas, B.; Ottermanns, R.; Ziefle, M.; Roß-Nickoll, M. Assessment of urban green space structures and their quality from a multidimensional perspective. Sci. Total Environ. 2018, 615, 1364-1378. [CrossRef] [PubMed]

85. Raszeja, E.; Skóra, A. Preservation of river valleys in Wielkopolska in the landscape perception terms-The case of the valley of Samica Kierska river. Acta Sci. Pol. Form. Circumiectus 2019, 1, 53-65. [CrossRef]

86. Bundred, S. Review of Bristol 2015 European Green Capital Year. Report to Bristol City Council; Bristol Design, Bristol City Council: Bristol, UK, 2016.

87. Tallon, A.R. Bristol. Cities 2007, 24, 74-88. [CrossRef]

88. Grant Associates Grant Associates-Bristol Harbourside. Available online: http://grant-associates.uk.com/ projects/bristol-harbourside-landscape-masterplan/ (accessed on 22 October 2017).

89. Poznań Municipal Urban Planning Office. The Study on Conditions and Spatial Development Directions for Poznań [in Polish]; the President of the City of Poznań: Poznań, Poland, 2018.

90. Parliament of the Republic of Poland. The Act on Spatial Planning [in Polish]; Parliament's of the Republic of Poland Office: Warsaw, Poland, 2003.

91. Walz, U. Indicators to monitor the structural diversity of landscapes. Ecol. Modell. 2015, 295, 88-106. [CrossRef]

92. Gdańsk Municipal Office. Gdańsk Public Information Bulletin [in Polish]. Available online: https://bip.gdansk.pl/ (accessed on 4 November 2018).

93. Poznań Municipal Urban Planning Office. Poznań Public Information Bulletin [in Polish]. Available online: http://bip.poznan.pl/ (accessed on 4 November 2018).

94. Gdańsk Development Office. The Study on Conditions and Spatial Development Directions for Gdańsk [in Polish]; the President of the City of Gdańsk: Gdańsk, Poland, 2018.

95. Pomeranian Land Management Office. Spatial Development Plan for Metropolitan Area of Gdańsk, Gdynia and Sopot 2030 [in Polish]; the Pomorskie Voivodeship Council: Gdańsk, Poland, 2017.

96. Centre for Metropolitan Reseach UAM Poznań. The Concept for Spatial Development for Metropolitan Area of Poznań [in Polish]; Kaczmarek, T., Mikuła, L., Eds.; Metropolitan Area of Poznań Association: Poznań, Poland, 2016.

97. Kabisch, N.; Strohbach, M.; Haase, D.; Kronenberg, J. Urban green space availability in European cities. Ecol. Indic. 2016, 70, 586-596. [CrossRef]

98. Niedźwiecka-Filipiak, I.; Rubaszek, J.; Potyrała, J.; Filipiak, P. The Method of Planning Green Infrastructure System with the Use of Landscape-Functional Units (Method LaFU) and its Implementation in the Wrocław Functional Area (Poland). Sustainability 2019, 11, 394. [CrossRef]

99. Szulczewska, B.; Giedych, R.; Maksymiuk, G. Can we face the challenge: how to implement a theoretical concept of green infrastructure into planning practice? Warsaw case study. Landsc. Res. 2017, 42, 176-194. [CrossRef]

100. Biernacka, J.; Erbel, J.; Augustynowicz, S.; Duda, T.; Gawryszewska, B.; Jurkiewicz, P.; Krzekotowska, J.; Rajkiewicz, A. The Warsaw Housing Standard 1.2 (draft project) [in Polish]; The Housing Policy Bureau of the City of Warsaw: Warsaw, Poland, 2018.

101. Parliament of the Republic of Poland. Act on amending certain other acts in connection with the reinforcement of the landscape protection instruments [in Polish]; Parliament's of the Republic of Poland Office: Warsaw, Poland, 2015.

102. Natural England and Department for Environment Food \& Rural Affairs Landscape and seascape character assessments. Available online: https://www.gov.uk/guidance/landscape-and-seascape-characterassessments (accessed on 7 November 2018).

103. Department for Communities and Local Government. Planning Policy Guidance 17: Planning for Open Space, Sport and Recreation; Office of the Deputy Prime Minister (ODPM): London, UK, 2006.

104. Tratalos, J.A.; Barbosa, O.; Fuller, R.A.; Davies, R.G.; Gaston, K.J.; Armsworth, P.R.; Johnson, P. Who benefits from access to green space? A case study from Sheffield, UK. Landsc. Urban Plan. 2007, 83, 187-195. 
105. Department of Communities and Local Government. Plain English guide to the Planning System; Ministry of Housing, Communities \& Local Government: London, UK, 2015.

106. Ministry of Housing Communities \& Local Government. Localism Act 2011; Parliament of the United Kingdom: London, UK, 2011.

107. Bristol City Council. Bristol Central Area Plan; Bristol Design, Bristol City Council: Bristol, UK, 2014.

108. Bristol City Council. Bristol Development Framework Core Strategy; Bristol Design, Bristol City Council: Bristol, UK, 2011.

109. Bristol City Council. Bristol's Parks and Green Space Strategy; Visual Technology, Bristol City Council: Bristol, UK, 2008.

110. Bristol Biodiversity Partnership. Bristol Biodiversity Action Plan-For People And Wildlife; King, S., Holland, H., Eds.; Bristol Biodiversity Partnership, Bristol Parks, Bristol City Council: Bristol, UK, 2008.

111. Bristol City Council. European Green Capital Award 2015-Bristol UK Technical Bid. Section 3 Green Urban Areas Incorporating Sustainable Land Use; European Commission, European Green Capital: Bristol, UK, 2015.

112. West of England Partnership; Natural England; Environment Agency; Forestry Commission. West of England Strategic Green Infrastructure Framework; West of England Green Infrastructure Group: Bristol, UK, 2011.

113. Park, C.Y.; Lee, D.K.; Asawa, T.; Murakami, A.; Kim, H.G.; Lee, M.K.; Lee, H.S. Influence of urban form on the cooling effect of a small urban river. Landsc. Urban Plan. 2019, 183, 26-35. [CrossRef]

114. Cullinan Studio Bristol Harbourside Masterplan. Available online: http://cullinanstudio.com/project/bristol_ harbourside_masterplan (accessed on 22 October 2017).

115. Nam, J.; Dempsey, N. Understanding Stakeholder Perceptions of Acceptability and Feasibility of Formal and Informal Planting in Sheffield's District Parks. Sustainability 2019, 11, 360. [CrossRef]

116. Tölle, A. Gdańsk. Cities 2008, 25, 107-119. [CrossRef]

117. Pierre, J. The politics of Urban Governance; Palgrave Macmillan: Basingstoke, UK, 2011.

118. Van den Dool, L.; Hendriks, F.; Gianoli, A.; Schaap, L. The quest for Good Urban Governance: Theoretical Reflections and International Practices; Springer: Wiesbaden, Germany, 2015.

119. Badach, J.; Dymnicka, M. Concept of 'Good Urban Governance' and Its Application in Sustainable Urban Planning. IOP Conf. Ser. Mater. Sci. Eng. 2017, 245, 082017. [CrossRef]

120. Beunen, R.; Opdam, P. When landscape planning becomes landscape governance, what happens to the science? Landsc. Urban Plan. 2011, 100, 324-326. [CrossRef]

121. Opdam, P.; Nassauer, J.I.; Wang, Z.; Albert, C.; Bentrup, G.; Castella, J.C.; McAlpine, C.; Liu, J.; Sheppard, S.; Swaffield, S. Science for action at the local landscape scale. Landsc. Ecol. 2013, 28, 1439-1445. [CrossRef]

122. Haase, D.; Frantzeskaki, N.; Elmqvist, T. Ecosystem Services in Urban Landscapes: Practical Applications and Governance Implications. Ambio 2014, 43, 407-412. [CrossRef]

123. Southern, A.; Lovett, A.; O’Riordan, T.; Watkinson, A. Sustainable landscape governance: Lessons from a catchment based study in whole landscape design. Landsc. Urban Plan. 2011, 101, 179-189. [CrossRef] 